art of Journal of Research of the National Bureau of Standards, Volume 28, June 1942

\title{
JEATHER RESISTANCE OF PORCELAIN-ENAMELED IRON STRUCTURAL UNITS
}

\author{
By William N. Harrison and Dwight G. Moore
}

\section{ABSTRACT}

A study of the weathering resistance of vitreous enameled architectural panels as begun by the National Bureau of Standards in 1939. The study involves $\approx 64$ one-foot-square panels, representing 14 types of enamel and a like number f 4 - by 6 -in. laboratory specimens. At the end of the first year of exposure at four locations selected for different climatic conditions, over half of the panels howed no visible weathering effect, and in no case did weathering produce any ailure of the enamel to protect the underlying metal from rusting.

The full-mat enamels were found unsuited for architectural use where appearance is important, because of fading and of difficulty in cleaning. Mild fading, found on some of the non-acid-resistant colored enamels, was associated with a minute pitting of the enamel surface, probably caused by the presence of acidforming gases in the atmosphere. The enamels of high acid resistance did not show this effect.

Weathering of the panels was found to be more pronounced at those locations where there is a relatively high concentration of combustion gases, and less severe where there is a practical absence of these gases in the atmosphere. An accelerated weathering test is described, which gives an effect closely resembling the most important form of actual weathering.

\section{CONTENTS}

I. Introduction - -

II. Conditions prevailing at locations of exposure 736

III. Description of the specimens and method of mounting

IV. Types and sources of the enamels _._. 738

V. Measurements prior to exposure of the panels _...

VI. Results of inspection of the panels after 1 year of exposure

1. Accumulation of dirt and ease of cleaning . . _........ 742

2. Visual examination after cleaning

(a) Glossiness _...

(b) Iridescence of black enamels _................ 743

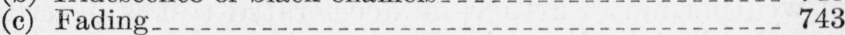

3. Microscopic examination _. _ . _ _ _

4. Measured color change

5. Specular-gloss measurements_...

VII. Accelerated weathering tests $\ldots$

1. Radiation tests

2. Autoclave tests_............ 747

3. Miscellaneous tests with water

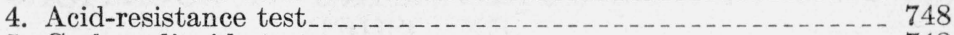

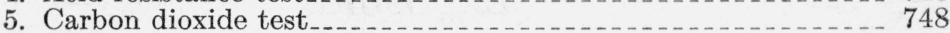

VIII. Surface coating to inhibit weathering

IX. Discussion _... 750

X. Summary

XI. References 


\section{INTRODUCTION}

During the past few years the increased use of porcelain enamel a an architectural material and the diminished availability of zinc and tin for use in roofing and siding have accentuated the need for adequate data on the weathering resistance of various types of porcelain enamel on architectural units.

That porcelain enamels, when properly selected, have excellent durability against the destructive action of weathering is widely recognized. For example, there are reliable reports of porcelainenameled street and advertising signs which have been exposed for as long as 25 years without apparent deterioration of the enamel. However, it is known by those familiar with their manufacture that not all enamels are equally resistant to weathering. Experience has shown that specialized types of porcelain enamel are frequently preferable for specific uses. One notable example is in the field of hot-water tanks, for which only properly selected enamels will give satisfactory results.

The present study was undertaken with the dual purpose of determining which types of enamel are the most resistant to weathering under various typical climatic conditions and of developing, if possible, an accelerated test by means of which the most durable types can be selected in the laboratory.

A review of the literature disclosed only two reports of systematic attempts to evaluate the relative weathering resistance of enamels of various types. Summarized results of these investigations, both of which were made by the same laboratory, are reported by Ammon [1] ${ }^{1}$ and by Sweo [2]. For the latter report, 6 - by 12 -inch specimens from 55 enamels prepared in one laboratory were exposed at Cleveland, Ohio, and Miami, Fla.

The present investigation was begun by the Enameled Metals Section of the National Bureau of Standards in 1939, and was planned with the assistance of an advisory committee from the industry. Through the cooperation of 16 different manufacturers, 864 one-footsquare panels and an equal number of 4 - by 6 -inch laboratory specimens were prepared. Most of the enamels furnished were regular commercial products, but they were not in all cases enamels which had been proved suitable for architectural purposes.

The present paper comprises a progress report covering the first year of weathering. Further, an accelerated test is described which correlates well with the results of actual weathering and appears to simulate the mechanism of the most important form of weathering. It is planned to present further data as the investigation continues and also a final report at the conclusion of the study.

\section{CONDITIONS PREVAILING AT LOCATIONS OF EXPOSURE}

The four different locations chosen for exposing the specimens are described briefly in table 1. At Washington, D. C. the supporting racks are located at the National Bureau of Standards, which is in a residential section of the city, but, because the stack of a heating plant is situated some 50 yards to the southwest of the racks, there

\footnotetext{
${ }^{1}$ Figures in brackets indicate the literature references at the end of this paper.
} 
may be considerably more combustion gases in the air under certain weather conditions than is normal for an average residential location. Computations indicated that this stack in midwinter may discharge into the atmosphere as much as 500 pounds of sulfur dioxide in 24 hours. Exhaust fans from chemical hoods also discharge into the atmosphere at several points around the Bureau grounds, but air contamination from this source is believed to be almost negligible.

The St. Louis, Mo. location is about 200 yards from the railroad terminal, which presumably is one of the most smoky sections of the city. The smoke-abatement ordinance of 1940 , which substantially reduced smoke concentrations in this section, was put into effect after the specimens were placed on test. However, there is still an abundance of combustion gases near the terminal, and it is believed that this location, even with the ordinance in effect, represents a severe industrial atmosphere.

TABLE 1.-Exposure-test locations

\begin{tabular}{|c|c|c|}
\hline City & Exposure site & Exposure conditions represented \\
\hline Washington, D. C & \multirow{4}{*}{$\begin{array}{l}\text { Roof, Industrial Bldg., National Bureau } \\
\text { of Standards. } \\
\text { Roof, Union Electric Co. warehouse } \\
\text { Ground, Municipal Airport- } \\
\text { Ground, U. S. Coast Guard Station. }\end{array}$} & \multirow{4}{*}{$\begin{array}{l}\text { Temperate, residential. } \\
\text { Temperate, industrial. } \\
\text { Semitropical, residential. } \\
\text { Temperate, "salt air". }\end{array}$} \\
\hline St. Louis, Mo & & \\
\hline $\begin{array}{l}\text { Lakeland, Fla } \\
\text { Atlantic City, N. J.- }\end{array}$ & & \\
\hline & & \\
\hline
\end{tabular}

At Lakeland, Fla. the racks are situated about 2 miles from the center of the city, which is about 35 miles inland from Tampa. The atmosphere can be considered representative of subtropical conditions, with practically no contamination from industrial sources.

At Atlantic City, N. J. the racks are located on the grounds of the new United States Coast Guard Station about a mile from the city proper. They are 30 yards from the shore of a protected cove and are in such a position as to be exposed to "salt air" without being subjected to a salt-water spray. However, under certain weather conditions, when the wind is from the southwest and the barometric pressure is low, there may well be some atmospheric contamination from city combustion gases.

TABLE 2.-General weather data for the first year of exposure

[From U. S. Weather Bureau records]

\begin{tabular}{|c|c|c|c|c|c|}
\hline City & Exposure period & $\begin{array}{l}\text { Total } \\
\text { rain- } \\
\text { fall }^{11}\end{array}$ & $\begin{array}{l}\text { Total } \\
\text { sun- } \\
\text { shine }{ }^{1}\end{array}$ & $\begin{array}{l}\text { Average } \\
\text { tempera- } \\
\text { ture } 1\end{array}$ & $\begin{array}{l}\text { Average sul- } \\
\text { fur dioxide } \\
\text { content }\end{array}$ \\
\hline $\begin{array}{l}\text { Washington, D. C...- } \\
\text { St. Louis, Mo.-.-.- } \\
\text { Lakeland, Fla.- } \\
\text { Atlantic City, N. J.-. }\end{array}$ & $\begin{array}{l}\text { Dec. } 1939 \text { through Nov. } 1940 \\
\text { Apr. } 1940 \text { through March } 1941 .- \\
\text { July } 1940 \text { through June } 1941 . \\
\text { Aug. } 1940 \text { through July } 1941 .\end{array}$ & $\begin{array}{l}\text { in. } \\
40.1 \\
24.4 \\
48.6 \\
37.4\end{array}$ & $\begin{array}{l}h r \\
2,344 \\
2,762 \\
2,751 \\
2,747\end{array}$ & $\begin{array}{l}{ }^{\circ} \mathrm{F} \\
54.5 \\
57.0 \\
71.1 \\
53.4\end{array}$ & $\begin{array}{r}\text { ppm, by vol. } \\
0.008 \\
\text { (3) } .366 \\
\text { (3) }\end{array}$ \\
\hline
\end{tabular}

1 Covers actual period of exposure.

2 Taken from Air Hygiene Foundation Bulletin No. 1 (1937).

${ }^{3}$ Not available.

At all four locations the racks face in a southern direction, the panels being exposed at $45^{\circ}$ from the horizontal. The $45^{\circ}$ angle has been found to promote weathering attack with organic finishes [3] and may be assumed to have a similar effect upon porcelain enamels. 
Pertinent data as to the atmospheric conditions at these fourlocations are given in table 2. These data were furnished by the United States Weather Bureau and cover the actual period of exposure. The sulfur-dioxide content is taken from an Air Hygiene Foundation report [4] and, in each case listed, the gas samples were taken within 300 yards of the actual exposure site. They, however, were taken before the exposure period.

\section{DESCRIPTION OF THE SPECIMENS AND METHOD OF MOUNTING}

The 1-foot-square panels being exposed at the several locations are fabricated of 16-gage iron and have 1-inch flanged edges. The flange on the lower side has a $1 / 2$-inch outward extension parallel to the face of the panel. Two clips made of 1-inch strip iron are welded to the top flange so as to extend downward. The clips and the lower flange extension fit into 18-gage galvanized-iron channels, which in turn were firmly attached to the supporting racks. The crevices between the specimens were not calked but were left open to facilitate removal of the panels during periods of inspection.

The supporting racks were constructed of $3 / 16$-inch angle iron and, after priming, were painted with aluminum paint. Each rack was constructed to support 28 of the 1-foot-square panels at an angle of $45^{\circ}$ to the horizontal.

Seven racks were required for each location. At those locations where the panels were exposed on flat roofs, the racks were anchored with weights, and at the ground locations the racks were anchored to piers of concrete blocks. Figure 1 shows the installation at Washington, D. C.

\section{TYPES AND SOURCES OF THE ENAMELS}

The 14 types of enamel included in the study are listed in table 3. Each of the four enamel frit manufacturers furnished all 14 types of frit, together with directions for mill additions ${ }^{2}$ and firing temperatures, making a total of 56 varieties of enamel. According to the original plan, 14 fabricators of enameled articles received these enamel frits for use in preparing the specimens. As shown in table 3, the distribution of the frits among the fabricators was such that each fabricator received two types of frit.

In the specimen identifications given in the first column of table 3 , the letters designate the enamel types; the numbers following the letters identify, by code, the source of the frit that was used for each specimen as well as the fabricator. Thus the specimens represented by numbers 1 to 8 and 11 to 18 for each enamel type were made from frit supplied by the first of the four frit manufacturers, 21 to 28 and 31 to 38 from frit supplied by the second, 41 to 48 and 51 to 58 by the third, and specimens 61 to 68 and 71 to 78 from frit supplied by the fourth manufacturer. For each type of enamel, the panels made by one fabricator were numbered 1 to 8,21 to 28,41 to 48 , and 61 to 68 , whereas the duplicates made by the other fabricator were numbered 11 to 18,31 to 38,51 to 58 , and 71 to 78 . In every case an additional

\footnotetext{
${ }^{2}$ In the preparation of an enamel for application to sheet iron, the enamel frit is ball-milled together with such ingredients as clay, opacifier, color oxide, electrolyte, and water. All of those materials added at the mill consitute the mill additions.
} 
specimen, assigned a number ending in "9," was made to keep in storage for comparison with exposed panels. By this arrangement, eight variables, the product of four frit sources and two fabricators, were to be introduced for each of the 14 enamel types. In four cases, however (types $B, C, D$, and $E$ in table 3 ), the four frit sources were actually the only variables, inasmuch as two fabricators who had originally planned to cooperate in the investigation were later unable to participate.

TABLE 3.-Percentage of initial specular gloss retained at 4 exposure locations at end of first year of weathering, together with summarized results of acid resistance and carbon dioxide tests on same compositions

\begin{tabular}{|c|c|c|c|c|c|c|c|c|c|}
\hline \multirow[b]{2}{*}{$\begin{array}{l}\text { Specimen identi- } \\
\text { fication }^{1}\end{array}$} & \multirow[b]{2}{*}{$\begin{array}{l}\text { Fabri- } \\
\text { cator }\end{array}$} & \multirow{2}{*}{$\begin{array}{l}\text { Aver- } \\
\text { age } \\
\text { initial } \\
\text { specu- } \\
\text { lar } \\
\text { gloss }\end{array}$} & \multicolumn{6}{|c|}{ A verage percentage of initial specular gloss retained 2} & \multirow{2}{*}{$\begin{array}{c}\text { Acid } \\
\text { resist- } \\
\text { ance } \\
\text { PEI } \\
\text { test }\end{array}$} \\
\hline & & & $\begin{array}{l}\text { Wash- } \\
\text { ing- } \\
\text { ton }\end{array}$ & $\begin{array}{l}\text { St. } \\
\text { Louis }\end{array}$ & $\begin{array}{l}\text { Atlan- } \\
\text { tic } \\
\text { City }\end{array}$ & $\begin{array}{l}\text { Lake- } \\
\text { land }\end{array}$ & $\begin{array}{c}\text { A verage } \\
\text { at } 4 \\
\text { locations }\end{array}$ & $\begin{array}{l}\mathrm{CO}_{2} \\
\text { test }^{3}\end{array}$ & \\
\hline
\end{tabular}

WHITE, GLOSSY, ACID-RESISTANT ENAMEL

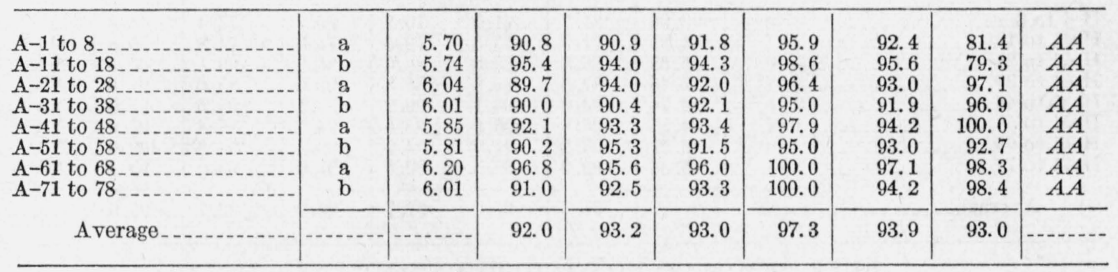

WHITE, GLOSSY, NON-ACID-RESISTANT ENAMEL

\begin{tabular}{|c|c|c|c|c|c|c|c|c|c|}
\hline $\begin{array}{l}\mathrm{B}-1 \text { to } 8 \\
\mathrm{~B}-21 \text { to } 28 \\
\mathrm{~B}-41 \text { to } 48 \\
\mathrm{~B}-61 \text { to } 68\end{array}$ & $\begin{array}{l}\mathrm{b} \\
\mathrm{b} \\
\mathrm{b} \\
\mathrm{b}\end{array}$ & $\begin{array}{l}\text { 5. } 26 \\
\text { 5. } 41 \\
\text { 5. } 16 \\
\text { 5. } 32\end{array}$ & $\begin{array}{l}69.8 \\
69.2 \\
71.8 \\
71.1\end{array}$ & $\begin{array}{l}84.3 \\
81.1 \\
81.7 \\
81.0\end{array}$ & $\begin{array}{l}85.4 \\
87.1 \\
87.8 \\
89.4\end{array}$ & $\begin{array}{l}86.5 \\
84.5 \\
80.6 \\
84.1\end{array}$ & $\begin{array}{l}81.5 \mathrm{P} \\
80.5 \mathrm{P} \\
80.5 \mathrm{P} \\
81.4 \mathrm{P}\end{array}$ & $\begin{array}{l}65.2 \\
73.1 \\
65.0 \\
69.7\end{array}$ & $\begin{array}{l}D \\
D \\
D \\
D\end{array}$ \\
\hline Average. & - & -....... & 70.5 & 82.0 & 88.1 & 83.9 & 81.1 & 68.2 & $\ldots$ \\
\hline
\end{tabular}

WHITE, SEMIMAT, ACID-RESISTANT ENAMEL

\begin{tabular}{|c|c|c|c|c|c|c|c|c|c|}
\hline $\begin{array}{l}\mathrm{C}-11 \text { to } 18 \\
\mathrm{C}-31 \text { to } 38 \\
\mathrm{C}-51 \text { to } 58 \\
\mathrm{C}-71 \text { to } 78\end{array}$ & $\begin{array}{l}\mathrm{c} \\
\mathrm{c} \\
\mathrm{c} \\
\mathrm{c}\end{array}$ & $\begin{array}{l}4.06 \\
5.24 \\
5.16 \\
5.32\end{array}$ & $\begin{array}{l}84.0 \\
85.8 \\
91.5 \\
95.7\end{array}$ & $\begin{array}{l}91.2 \\
92.7 \\
87.3 \\
93.8\end{array}$ & $\begin{array}{l}83.4 \\
86.5 \\
92.2 \\
90.4\end{array}$ & $\begin{array}{r}76.7 \\
91.5 \\
92.6 \\
100.0\end{array}$ & $\begin{array}{l}83.8 \\
89.1 \\
90.9 \\
95.0\end{array}$ & $\begin{array}{l}80.0 \\
97.3 \\
95.6 \\
96.0\end{array}$ & $\begin{array}{l}B \\
A \\
A A \\
A A\end{array}$ \\
\hline Average & -...... & $\ldots$ & 91.0 & 91.3 & 89.7 & 94.7 & 91.7 & 96.3 & -- \\
\hline
\end{tabular}

WHITE, SEMIMAT, NON-ACID-RESISTANT ENAMEL

\begin{tabular}{|c|c|c|c|c|c|c|c|c|c|}
\hline $\begin{array}{l}\mathrm{D}-1 \text { to } 8 \\
\mathrm{D}-21 \text { to } 28 \\
\mathrm{D}-41 \text { to } 48 \\
\mathrm{D}-61 \text { to } 68\end{array}$ & $\begin{array}{l}\mathrm{c} \\
\mathrm{c} \\
\mathrm{c} \\
\mathrm{c}\end{array}$ & $\begin{array}{l}\left({ }^{6}\right) \\
5.69 \\
5.51 \\
(6)\end{array}$ & $\begin{array}{r}70.5 \\
74.0\end{array}$ & $\begin{array}{r}79.7 \\
76.1 \\
-7\end{array}$ & $\begin{array}{r}82.9 \\
81.0\end{array}$ & $\begin{array}{r}87 . \overline{5} \\
88.3 \\
-\end{array}$ & $\begin{array}{r}80.2 \mathrm{P} \\
79.8 \mathrm{P} \\
-9.9\end{array}$ & $\begin{array}{r}75.7 \\
80.9 \\
-\end{array}$ & $\begin{array}{l}D \\
D \\
D \\
D\end{array}$ \\
\hline Average & $-\ldots$ & $\ldots$ & 72.2 & 77.9 & 81.9 & 87.9 & 80.0 & 78.3 & -- \\
\hline
\end{tabular}

BUFF, GLOSSY, ACID-RESISTANT ENAMEL

\begin{tabular}{|c|c|c|c|c|c|c|c|c|c|}
\hline $\begin{array}{l}\mathrm{E}-11 \text { to } 18 \\
\mathrm{E}-31 \text { to } 38 \\
\mathrm{E}-51 \text { to } 58\end{array}$ & $\begin{array}{l}d \\
d \\
d \\
d\end{array}$ & $\begin{array}{l}5.09 \\
5.43 \\
5.44 \\
5.35\end{array}$ & $\begin{array}{l}83.8 \\
90.8 \\
91.6 \\
96.1\end{array}$ & $\begin{array}{l}91.9 \\
94.8 \\
93.8 \\
99.5\end{array}$ & $\begin{array}{l}82.8 \\
92.0 \\
92.2 \\
96.1\end{array}$ & $\begin{array}{l}80.5 \\
93.1 \\
96.3 \\
99.7\end{array}$ & $\begin{array}{l}84.8 \\
92.7 \\
93.5 \\
97.8\end{array}$ & $\begin{array}{l}76.4 \\
97.3 \\
79.0 \\
99.2\end{array}$ & $\begin{array}{l}B \\
A A \\
A A \\
A A\end{array}$ \\
\hline Average & $\ldots$ & $\ldots$ & 92.8 & 96.0 & 93.4 & 96.4 & 94.7 & 91.8 & $-\ldots$ \\
\hline
\end{tabular}

See footnotes at end of table. 
TABLE 3.-Percentage of initial specular gloss retained at 4 exposure locations at end of first year of weathering, together with summarized results of acid resistance and carbon dioxide tests on same compositions-Continued

\begin{tabular}{|c|c|c|c|c|c|c|c|c|c|}
\hline \multirow{2}{*}{$\begin{array}{l}\text { Specimen identi- } \\
\text { fication }^{1}\end{array}$} & \multirow{2}{*}{$\begin{array}{l}\text { Fabri- } \\
\text { cator }\end{array}$} & \multirow{2}{*}{$\begin{array}{c}\text { A ver- } \\
\text { age } \\
\text { intial } \\
\text { specu- } \\
\text { lar } \\
\text { gloss }\end{array}$} & \multicolumn{6}{|c|}{ A verage percentage of initial specular gloss retained 2} & \multirow{2}{*}{$\begin{array}{l}\text { Acid } \\
\text { resist- } \\
\text { ance } \\
\text { PEI } \\
\text { test }\end{array}$} \\
\hline & & & $\begin{array}{l}\text { Wash- } \\
\text { ing- } \\
\text { ton }\end{array}$ & $\begin{array}{l}\text { St. } \\
\text { Louis }\end{array}$ & $\begin{array}{c}\text { Atlan- } \\
\text { tic } \\
\text { City }\end{array}$ & $\begin{array}{l}\text { Lake- } \\
\text { land }\end{array}$ & $\begin{array}{l}\text { A verage } \\
\text { at } 4 \\
\text { locations }\end{array}$ & $\begin{array}{l}\mathrm{CO}_{2} \\
\text { test }^{3}\end{array}$ & \\
\hline
\end{tabular}

BUFF, GLOSSY, NON-ACID-RESISTANT ENAMEL

\begin{tabular}{|c|c|c|c|c|c|c|c|c|c|}
\hline $\begin{array}{l}\mathrm{F}-1 \text { to } 8 \\
\mathrm{~F}-11 \text { to } 18 \text { to } 28 \\
\mathrm{~F}-31 \text { to } 38 \\
\mathrm{~F}-41 \text { to } 48 \\
\mathrm{~F}-61 \text { to } 58 \\
\mathrm{~F}-71 \text { to } 78\end{array}$ & $\begin{array}{l}\text { d } \\
\text { e } \\
d \\
\text { e } \\
d \\
\text { e } \\
d \\
\text { e }\end{array}$ & $\begin{array}{l}5.15 \\
4.87 \\
5.02 \\
5.56 \\
4.31 \\
5.66 \\
4.64 \\
5.26\end{array}$ & $\begin{array}{l}72.1 \\
90.2 \\
72.1 \\
69.0 \\
71.3 \\
74.1 \\
61.2 \\
62.6\end{array}$ & $\begin{array}{l}77.7 \\
96.0 \\
77.1 \\
77.0 \\
83.9 \\
71.2 \\
69.0 \\
81.6\end{array}$ & $\begin{array}{l}83.2 \\
92.2 \\
92.2 \\
76.4 \\
83.9 \\
77.0 \\
85.1 \\
83.9\end{array}$ & $\begin{array}{l}92.6 \\
93.7 \\
95.5 \\
84.9 \\
87.8 \\
84.3 \\
82.6 \\
86.2\end{array}$ & $\begin{array}{l}\text { 81. } 4 \mathrm{P} \\
93.0 \mathrm{P} \\
84.2 \mathrm{P} \\
76.8 \mathrm{P} \\
81.7 \mathrm{P} \\
76.6 \mathrm{P} \\
74.5 \mathrm{P} \\
76.8 \mathrm{P}\end{array}$ & $\begin{array}{l}77.8 \\
89.2 \\
78.8 \\
55.4 \\
85.8 \\
89.2 \\
74.9 \\
93.6\end{array}$ & $\begin{array}{l}D \\
D \\
D \\
D \\
D \\
D \\
D \\
D\end{array}$ \\
\hline Average & 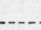 & 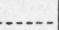 & 71.6 & 79.2 & 84.2 & 88.4 & 80.8 & 80.6 & $\ldots$ \\
\hline
\end{tabular}

BUFF, SEMIMAT, ACID-RESISTANT ENAMEL

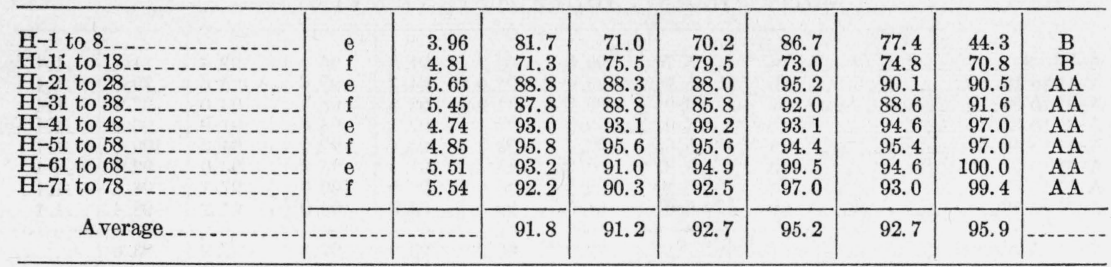

BUFF, SEMIMAT, NON-ACID-RESISTANT ENAMEL

\begin{tabular}{|c|c|c|c|c|c|c|c|c|c|}
\hline $\begin{array}{l}\mathrm{K}-1 \text { to } 8 \\
\mathrm{~K}-11 \text { to } 18 \\
\mathrm{~K}-21 \text { to } 28 \\
\mathrm{~K}-31 \text { to } 38 \\
\mathrm{~K}-41 \text { to } 48 \\
\mathrm{~K}-51 \text { to } 58 \\
\mathrm{~K}-61 \text { to } 68 \\
\mathrm{~K}-71 \text { to } 78\end{array}$ & $\begin{array}{l}\text { f } \\
g \\
\text { f } \\
g \\
\text { f } \\
g \\
\text { f } \\
g\end{array}$ & $\begin{array}{l}(6) \\
(6) \\
5.41 \\
5.37 \\
5.20 \\
5.35 \\
(6) \\
(6)\end{array}$ & $\begin{array}{r}70.7 \\
65.9 \\
79.6 \\
69.9 \\
\end{array}$ & $\begin{array}{r}80.9 \\
79.5 \\
85.1 \\
73.5 \\
- \\
\end{array}$ & $\begin{array}{r}76.8 \\
77.2 \\
83.4 \\
84.1 \\
-\end{array}$ & $\begin{array}{r}86.2 \\
88.1 \\
88.7 \\
82.7 \\
-\end{array}$ & $\begin{array}{r}78.6 \mathrm{P} \\
77.7 \mathrm{P} \\
77.6 \mathrm{P} \\
7\end{array}$ & $\begin{array}{r}64.8 \\
65.5 \\
76.4 \\
67.1 \\
\\
\end{array}$ & $\begin{array}{l}D \\
D \\
D \\
D \\
D \\
D \\
D \\
D \\
D\end{array}$ \\
\hline Average & - & & 71.5 & 79.7 & 80.4 & 86.4 & 79.5 & 68.4 & \\
\hline
\end{tabular}

RED, GLOSSY, ACID-RESISTANT ENAMEL

\begin{tabular}{|c|c|c|c|c|c|c|c|c|c|}
\hline $\begin{array}{l}\mathrm{L}-1 \text { to } 8 \\
\mathrm{~L}-11 \text { to } 18 \\
\mathrm{~L}-21 \text { to } 28 \\
\mathrm{~L}-31 \text { to } 38 \\
\mathrm{~L}-41 \text { to } 48 \\
\mathrm{~L}-51 \text { to } 58 \\
\mathrm{~L}-61 \text { to } 68 \\
\mathrm{~L}-71 \text { to } 78\end{array}$ & $\begin{array}{l}\mathrm{g} \\
\mathrm{h} \\
\mathrm{g} \\
\mathrm{h} \\
\mathrm{g} \\
\mathrm{h} \\
\mathrm{g} \\
\mathrm{h}\end{array}$ & $\begin{array}{l}5.58 \\
5.61 \\
5.42 \\
5.64 \\
5.58 \\
5.23 \\
5.30 \\
4.18\end{array}$ & $\begin{array}{l}85.6 \\
83.7 \\
85.4 \\
86.4 \\
85.1 \\
86.9 \\
88.0 \\
87.8\end{array}$ & $\begin{array}{l}85.2 \\
82.8 \\
84.5 \\
86.3 \\
81.5 \\
89.0 \\
86.1 \\
91.6\end{array}$ & $\begin{array}{l}83.2 \\
82.0 \\
85.7 \\
87.5 \\
81.2 \\
83.6 \\
86.1 \\
91.1\end{array}$ & $\begin{array}{l}84.7 \\
84.4 \\
88.1 \\
85.9 \\
87.8 \\
89.9 \\
90.7 \\
81.7\end{array}$ & $\begin{array}{l}84.7 \\
83.2 \\
85.9 \\
86.5 \\
83.9 \\
87.4 \\
87.7 \\
88.0\end{array}$ & $\begin{array}{r}96.4 \\
98.1 \\
80.0 \\
84.0 \\
100.0 \\
100.0 \\
98.0 \\
97.9\end{array}$ & $\begin{array}{l}\text { AA } \\
\text { AA } \\
\text { B } \\
\text { B } \\
\text { AA } \\
\text { AA } \\
\text { AA } \\
\text { AA }\end{array}$ \\
\hline Average_. & $\mid-\ldots \ldots$ & $\ldots$ & 86.2 & 86.0 & 84.5 & 86.5 & 85.8 & 98.4 & - \\
\hline
\end{tabular}

RED, GLOSSY, NON-ACID-RESISTANT ENAMEL

\begin{tabular}{|c|c|c|c|c|c|c|c|c|c|}
\hline $\begin{array}{l}\mathrm{N}-1 \text { to } 8 \\
\mathrm{~N}-11 \text { to } 18 \\
\mathrm{~N}-21 \text { to } 28 \\
\mathrm{~N}-31 \text { to } 38 \\
\mathrm{~N}-41 \text { to } 48 \\
\mathrm{~N}-51 \text { to } 58 \\
\mathrm{~N}-61 \text { to } 68\end{array}$ & $\begin{array}{l}\mathrm{h} \\
\mathrm{k} \\
\mathrm{h} \\
\mathrm{k} \\
\mathrm{h} \\
\mathrm{k} \\
\mathrm{h} \\
\mathrm{k}\end{array}$ & $\begin{array}{l}5.17 \\
5.05 \\
5.12 \\
4.55 \\
5.17 \\
4.68 \\
4.71 \\
5.44\end{array}$ & $\begin{array}{l}76.3 \\
82.8 \\
85.1 \\
88.4 \\
71.8 \\
74.0 \\
67.8 \\
65.8\end{array}$ & $\begin{array}{l}76.8 \\
82.3 \\
84.6 \\
(7) \\
73.1 \\
80.0 \\
77.3 \\
66.0\end{array}$ & $\begin{array}{l}80.8 \\
78.4 \\
79.1 \\
90.4 \\
76.8 \\
80.4 \\
81.4 \\
76.1\end{array}$ & $\begin{array}{l}86.4 \\
84.7 \\
82.3 \\
95.2 \\
79.0 \\
81.8 \\
89.1 \\
(7)\end{array}$ & $\begin{array}{l}\text { 80.1 } \mathrm{P} \\
\text { 82.0 } \mathrm{P} \\
82.8 \mathrm{P} \\
91.3 \mathrm{P} \\
75.2 \mathrm{P} \\
79.0 \mathrm{P} \\
78.6 \mathrm{P} \\
69.3 \mathrm{P}\end{array}$ & $\begin{array}{l}76.9 \\
75.2 \\
81.9 \\
76.7 \\
75.4 \\
81.2 \\
75.7 \\
72.3\end{array}$ & $\begin{array}{l}\mathrm{C} \\
\mathrm{C} \\
\mathrm{D} \\
\mathrm{D} \\
\mathrm{C} \\
\mathrm{C} \\
\mathrm{C} \\
\mathrm{C}\end{array}$ \\
\hline Average & & & 76.5 & 77.2 & 80.4 & 85.5 & 79.9 & 77.0 & \\
\hline
\end{tabular}

See footnotes at end of table. 
TABLE 3.-Percentage of initial specular gloss retained at 4 exposure locations at end of first year of weathering, together with summarized results of acid resistance and carbon dioxide tests on same compositions-Continued

\begin{tabular}{|c|c|c|c|c|c|c|c|c|c|}
\hline \multirow[b]{2}{*}{$\begin{array}{l}\text { Specimen identi- } \\
\text { fication }^{1}\end{array}$} & \multirow[b]{2}{*}{$\begin{array}{l}\text { Fabri- } \\
\text { cator }\end{array}$} & \multirow{2}{*}{$\begin{array}{l}\text { Aver- } \\
\text { age } \\
\text { initial } \\
\text { specu- } \\
\text { lar } \\
\text { gloss }\end{array}$} & \multicolumn{6}{|c|}{ A verage percentage of initial specular gloss retained ${ }^{2}$} & \multirow{2}{*}{$\begin{array}{c}\text { Acid } \\
\text { resist- } \\
\text { ance } \\
\text { PEI } \\
\text { test }\end{array}$} \\
\hline & & & $\begin{array}{l}\text { Wash- } \\
\text { ing- } \\
\text { ton }\end{array}$ & $\begin{array}{l}\text { St. } \\
\text { Louis }\end{array}$ & $\begin{array}{c}\text { Atlan- } \\
\text { tic } \\
\text { City }\end{array}$ & $\begin{array}{l}\text { Lake- } \\
\text { land }\end{array}$ & $\begin{array}{l}\text { A verage } \\
\text { at } 4 \\
\text { locations }\end{array}$ & $\begin{array}{l}\mathrm{CO}_{2} \\
\text { test }^{3}\end{array}$ & \\
\hline
\end{tabular}

RED, SEMIMAT, ACID-RESISTANT ENAMEI,

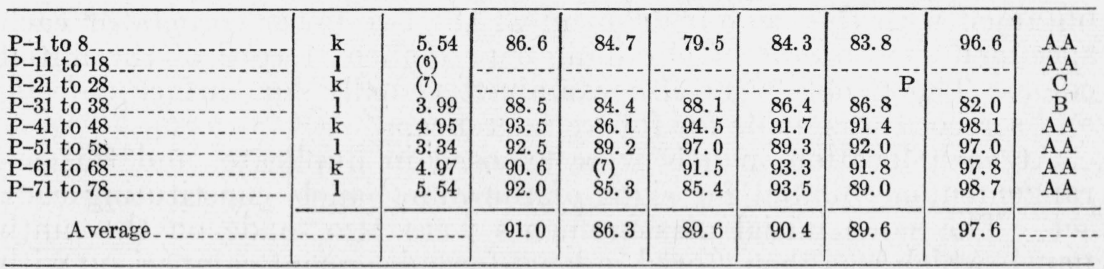

RED, SEMIMAT, NON-ACID-RESISTANT ENAMEL

\begin{tabular}{|c|c|c|c|c|c|c|c|c|c|}
\hline $\begin{array}{l}\text { S-1 to } 8 \\
\text { S-11 to } 18 \\
\text { S-21 to } 28 \\
\text { S-31 to } 38 \\
\text { S-41 to } 48 \\
\text { S-51 to } 58 \\
\text { S-61 to } 68 \\
\text { S-71 to } 78\end{array}$ & $\begin{array}{c}1 \\
\mathrm{~m} \\
1 \\
\mathrm{~m} \\
\mathrm{~m} \\
\mathrm{~m} \\
\mathrm{~m}\end{array}$ & $\begin{array}{l}(6) \\
(6) \\
4.51 \\
4.51 \\
3.50 \\
3.95 \\
4.50 \\
3.57\end{array}$ & $\begin{array}{l}78.2 \\
70.2 \\
80.4 \\
93.9 \\
64.7 \\
93.4\end{array}$ & $\begin{array}{l}86.2 \\
84.3 \\
81.7 \\
96.5 \\
73.9 \\
98.7\end{array}$ & $\begin{array}{l}74.8 \\
75.8 \\
83.4 \\
99.1 \\
74.8 \\
94.2\end{array}$ & $\begin{array}{r}73.8 \\
70.0 \\
72.9 \\
92.5 \\
87.6 \\
100.0\end{array}$ & $\begin{array}{l}78.2 \\
75.1 \mathrm{P} \\
79.6 \\
95.5 \\
75.2 \mathrm{P} \\
96.6 \mathrm{P}\end{array}$ & $\begin{array}{l}81.7 \\
66.2 \\
82.3 \\
87.9 \\
76.3 \\
73.8\end{array}$ & $\begin{array}{l}D \\
D \\
B \\
B \\
B \\
B \\
B \\
C \\
C\end{array}$ \\
\hline Average & - & - & 80.1 & 85.2 & 83.7 & 82.8 & 83.4 & 78.0 & \\
\hline
\end{tabular}

BLACK, GLOSSY, ACID-RESISTANT ENAMEL

\begin{tabular}{|c|c|c|c|c|c|c|c|c|c|}
\hline $\begin{array}{l}\mathrm{T}-1 \text { to } 8 \\
\mathrm{~T}-11 \text { to } 18 \\
\mathrm{~T}-21 \text { to } 28 \\
\mathrm{~T}-31 \text { to } 38 \\
\mathrm{~T}-41 \text { to } 48 \\
\mathrm{~T}-51 \text { to } 58 \\
\mathrm{~T}-61 \text { to } 68 \\
\mathrm{~T}-71 \text { to } 78\end{array}$ & $\begin{array}{l}\mathrm{m} \\
\mathrm{n} \\
\mathrm{m} \\
\mathrm{n} \\
\mathrm{m} \\
\mathrm{n} \\
\mathrm{m} \\
\mathrm{n}\end{array}$ & $\begin{array}{l}7.30 \\
6.60 \\
5.38 \\
5.55 \\
6.09 \\
5.90 \\
6.55 \\
6.56\end{array}$ & $\begin{array}{l}72.6 \\
93.7 \\
92.0 \\
93.0 \\
91.0 \\
92.3 \\
86.8 \\
78.5\end{array}$ & $\begin{array}{l}79.7 \\
92.8 \\
92.2 \\
88.5 \\
88.1 \\
86.7 \\
83.8 \\
76.9\end{array}$ & $\begin{array}{l}74.1 \\
92.3 \\
92.6 \\
95.4 \\
93.4 \\
91.3 \\
81.0 \\
67.0\end{array}$ & $\begin{array}{l}76.1 \\
93.5 \\
92.3 \\
95.2 \\
96.1 \\
94.7 \\
88.7 \\
73.0\end{array}$ & $\begin{array}{l}75.6 \\
93.1 \\
92.3 \\
93.0 \\
92.2 \\
91.2 \\
85.1 \\
73.8\end{array}$ & $\begin{array}{l}85.2 \\
99.8 \\
97.0 \\
96.5 \\
97.7 \\
98.2 \\
99.6 \\
96.6\end{array}$ & $\begin{array}{l}\text { AA } \\
\text { AA } \\
\text { AA } \\
\text { AA } \\
\text { AA } \\
\text { AA } \\
\text { AA } \\
\text { AA }\end{array}$ \\
\hline Average & & & 87.5 & 86.1 & 86.0 & 88.7 & 87.0 & 95.7 & \\
\hline
\end{tabular}

BLACK, GLOSSY, NON-ACID-RESISTANT ENAMEL

\begin{tabular}{|c|c|c|c|c|c|c|c|c|c|}
\hline $\begin{array}{l}\mathrm{V}-1 \text { to } 8 \\
\mathrm{~V}-11 \text { to } 18 \\
\mathrm{~V}-21 \text { to } 28 \\
\mathrm{~V}-31 \text { to } 38 \\
\mathrm{~V}-41 \text { to } 48 \\
\mathrm{~V}-51 \text { to } 58 \\
\mathrm{~V}-61 \text { to } 68 \\
\mathrm{~V}-71 \text { to } 78\end{array}$ & $\begin{array}{l}\mathrm{n} \\
\mathrm{a} \\
\mathrm{n} \\
\mathrm{a} \\
\mathrm{n} \\
\mathrm{a} \\
\mathrm{n} \\
\mathrm{a}\end{array}$ & $\begin{array}{l}\text { 5. } 52 \\
5.62 \\
5.76 \\
5.60 \\
5.30 \\
5.49 \\
4.67 \\
5.45\end{array}$ & $\begin{array}{l}76.0 \\
74.0 \\
68.8 \\
65.8 \\
75.5 \\
71.9 \\
83.2 \\
78.6\end{array}$ & $\begin{array}{l}76.8 \\
80.4 \\
68.0 \\
68.7 \\
75.8 \\
72.0 \\
90.8 \\
83.4\end{array}$ & $\begin{array}{l}71.1 \\
77.0 \\
72.8 \\
70.8 \\
76.4 \\
76.1 \\
89.2 \\
80.6\end{array}$ & $\begin{array}{l}88.5 \\
80.4 \\
77.1 \\
84.1 \\
80.8 \\
78.7 \\
86.9 \\
83.7\end{array}$ & $\begin{array}{l}78.1 \mathrm{P} \\
78.0 \mathrm{P} \\
71.7 \mathrm{P} \\
72.4 \mathrm{P} \\
77.1 \mathrm{P} \\
74.7 \mathrm{P} \\
87.5 \mathrm{P} \\
81.6 \mathrm{P}\end{array}$ & $\begin{array}{l}88.9 \\
76.8 \\
90.0 \\
81.7 \\
76.8 \\
81.1 \\
78.1 \\
70.3\end{array}$ & $\begin{array}{l}\mathrm{C} \\
\mathrm{C} \\
\mathrm{C} \\
\mathrm{C} \\
\mathrm{C} \\
\mathrm{C} \\
\mathrm{C} \\
\mathrm{C}\end{array}$ \\
\hline Average & & - & 74.2 & 77.0 & 76.8 & 82.5 & 77. 6 & 83.0 & $\ldots$ \\
\hline
\end{tabular}

1 Groups of 8 panels exposed, 2 at each location. Ninth panel kept in storage.

2 Values are average of 2 panels with 2 readings on each panel. Group averages for nominally Acid-resistant groups do not include values for specimens of class $C$ or lower acid resistance.

3 All tests made with specimen immersed in distilled water and under a carbon dioxide pressure of 4 in. of mercury for 17 hours at $26^{\circ} \pm 2^{\circ} \mathrm{C}$.

4 Test made according to Porcelain Enamel Institute standard acid-resistance test for flatware issued April 1940.

5 Enamels marked with a "P" after the four-location average are known to have pitted after 1 year at 1 or more of the 4 locations. In general, the lower the percent gloss retained for those enamels marked "P," the more pronounced was the pitting.

6 Full-mat enamels-initial gioss too low for measurement.

7 Panels badly warped-impossible to make proper gloss measurements. 


\section{MEASUREMENTS PRIOR TO EXPOSURE OF THE PANELS}

Before the panels were exposed at the indicated locations, several of their properties were measured and recorded. They were first washed with a warm 1-percent solution of trisodium phosphate, thoroughly rinsed in hot tap water, and dried in air. Specular-gloss measurements were made with the Hunter Multipurpose Reflectometer [5] at two fixed locations near the center of the surface to be exposed. Reflectance values with blue, green, and amber filters were obtained with the same instrument at the two lower corners of each specimen as a means of obtaining a permanent record of the initial color. The panels were also examined visually for surface defects, and a record was made for future reference.

At each location, panels were exposed in duplicate, and this arrangement accounted for eight of the nine panels constituting each set. The same initial measurements were also made on the ninth panel, which was then stored indoors for subsequent comparison with exposed panels.

\section{RESULTS OF INSPECTION OF THE PANELS AFTER 1 YEAR OF EXPOSURE}

At the conclusion of the first year of exposure, the specimens were examined for any evidence of changes in the enamel surface. They were first prepared for inspection by washing two-thirds of the exposed surface of each specimen with a warm 1-percent trisodium phosphate solution, rinsing in hot water, and drying in air. A vertical strip 4 inches wide along the left side of each specimen was left undisturbed. All specimens were examined visually and tested for specular gloss before being replaced in the racks. Selected specimens were also examined microscopically, and, in a few cases of noticeable color change, color measurements were made before the specimens were replaced in the racks.

\section{ACCUMULATION OF DIRT AND EASE OF CLEANING}

Difficulty in cleaning the panels was encountered only after their exposure at St. Louis. At the three other locations, the natural cleaning action of rains was apparently sufficient to keep the surfaces of the panels, except those with full-mat finish, ${ }^{3}$ relatively clean, and any deposit that was present could readily be removed by washing with the 1-percent trisodium phosphate solution. At St. Louis, however, the panel surfaces were covered with a strongly adhering coating resembling soot, which was not removed by rain. Washing the panels with 1 percent trisodium phosphate removed the top layer of this coating but left a visible film which required a scouring agent for its removal. This film was present on both the acid-resistant and non-acid-resistant enamels but seemed to adhere more tenaciously to the latter type of surface.

The full-mat enamels exposed at St. Louis were difficult to clean effectively, even by scouring. This was also true, to a lesser degree, at the other locations. In general, the acid-resistant enamels were

'Some of the "semimat" enamels were furnished in what might more properly be called full-mat textures. 
more easily cleaned than the non-acid-resistant, but this factor was not as important as that of surface texture, namely, whether the surface was of glossy, semimat, or full-mat texture.

\section{VISUAL EXAMINATION AFTER CLEANING}

The visual inspection, after the panels were cleaned, showed that in no case did weathering produce any failure of the enamel coatings to protect the underlying metal from rusting. Also, except for some of the full-mat enamels, none of the enamel surfaces showed any obvious change in appearance. However, when a careful inspection was made, using the corresponding storage panels as comparison standards, it was possible to detect slight changes in the surface appearance of a number of the specimens. These changes fell in the categories of glossiness, iridescence, and fading.

(a) GLOSSINESS

The necessity of comparing exposed panels with storage panels to detect changes in appearance was especially apparent in the visual inspection for glossiness. Panels which were originally classified as glossy, semimat, or mat, in every case retained the same classification when examined. Even in juxtaposition with storage panels, no change in glossiness was readily apparent from visual inspection of the acidresistant panels. A number of the glossy specimens of non-acidresistant enamel did show visible changes in glossiness however when compared with the corresponding storage panels. Since the specimens had been washed with a 1-percent solution of trisodium phosphate prior to inspection, it is evident that the original appearance could not readily be restored by washing.

\section{(b) IRIDESCENCE OF BLACK ENAMELS}

The most noticeable change in appearance of the glossy specimens, after the first year of exposure, occurred on some of the black panels of both acid-resistant and non-acid-resistant compositions. These particular panels, all of which were made by the same fabricator, were found to have a slight scum or bloom over parts of the surface before exposure. This scum, in most cases, was of a pattern such as might be formed from stacking the panels in the plant after firing. This condition became much more pronounced during weathering and, after a year of exposure, took the form of an iridescent film which could be removed only by vigorous polishing with a scouring agent. The exact cause of the scumming on the panels before exposure has not been definitely determined, but, from available evidence, including consultation with the fabricator, it is believed to be due to storage in the plant where fumes from the furnace or pickling room were active.

(c) FADING

On most specimens, no visible fading had occurred. None of the glossy, acid-resistant panels showed any detectable color change, but in a few of the other enamels there was evidence that some fading had taken place. This effect was pronounced on the full-mat enamels of both non-acid-resistant and acid-resistant types. Fading, to a degree that could be detected visually, was evidenced on a small minority 
of the colored, nonacid-resistant, glossy specimens, but it was of a different type from that noted on the mat surfaces. It was found that, when these glossy panels were subjected to careful visual examination under proper lighting conditions, numerous tiny pits distributed over the enamel surface could be discerned. These pits had become an integral part of the surface texture and could not be removed by washing, boiling in water for 1 hour, or by scouring. They were particularly noticeable on the black and red, non-acid-resistant panels, where they appeared as minute white specks, thus making the original color appear lighter and weaker. This pitting occurred on the same varieties of enamels at all four locations, but appeared to be much less pronounced at Lakeland than at St. Louis, Washington, and Atlantic City.

On the basis of visual appearance only, weathered panels have sometimes been referred to as "scummed." Unless there is a removable surface deposit, however, it is thought that "faded" is a more descriptive term.

\section{MICROSCOPIC EXAMINATION}

A metallographic microscope was used to examine the surfaces of many of the specimens at the conclusion of the first year of exposure, and photomicrographs were taken of a number of representative panels.

Surfaces typical of enamels of high weather resistance are shown in figures 2,3 , and 4 . In these enamels, no significant change can be seen in the surface microstructure, and the panels have not changed in general appearance to any noticeable extent. Almost half of the specimens exposed were of this class of weather resistance. The appearance of the specimens shown in figures 2,3 , and 4 , as revealed by the microscope, suggests the presence of numerous surface irregularities which might produce an unsatisfactory appearance to the naked eye. Such is not the case, however. The enamels represented in figures 2 and 3 appear uniform and glossy to the naked eye, and that in figure 4 appears uniform and semiglossy.

In the previous section it is stated that the enamels of poor acid resistance, in many cases, were pitted. Figure 5 shows a typical pitted surface of an exposed specimen having class " $C$ " acid resistance $[6]^{4}$ as compared with the storage specimen of the same enamel. The pits at the upper right corner of the photomicrograph of the exposed panel, $E$, were apparently caused by tiny flakes of enamel actually leaving the surface. The large single pit to the left on the lower edge showed colored interference lines, indicating that, while an area of surface had been ruptured, the flake itself still adhered, however weakly, to the underlying enamel. In either case, the flakes penetrate only to a depth of the order of 0.0001 inch into the enamel and do not exceed a diameter of $0.002 \mathrm{inch}$. Nevertheless, they produce optical effects which make the panel surface appear faded or scummed.

In no case was any enamel having an acid resistance of class $A$ or class $A A$ found to be pitted when examined with the microscope,

\footnotetext{
${ }_{4}$ The classification for acid resistance, as used in this paper, is in accordance with the Porcelain Enamel institute test for the acid resistance of flatware. In this test, class $A A$ is the most resistant, with class $A$, class $B$, class $C$, and class $D$ following in that order. Enamels falling in the latter two classes are not considered as acid resistant.
} 


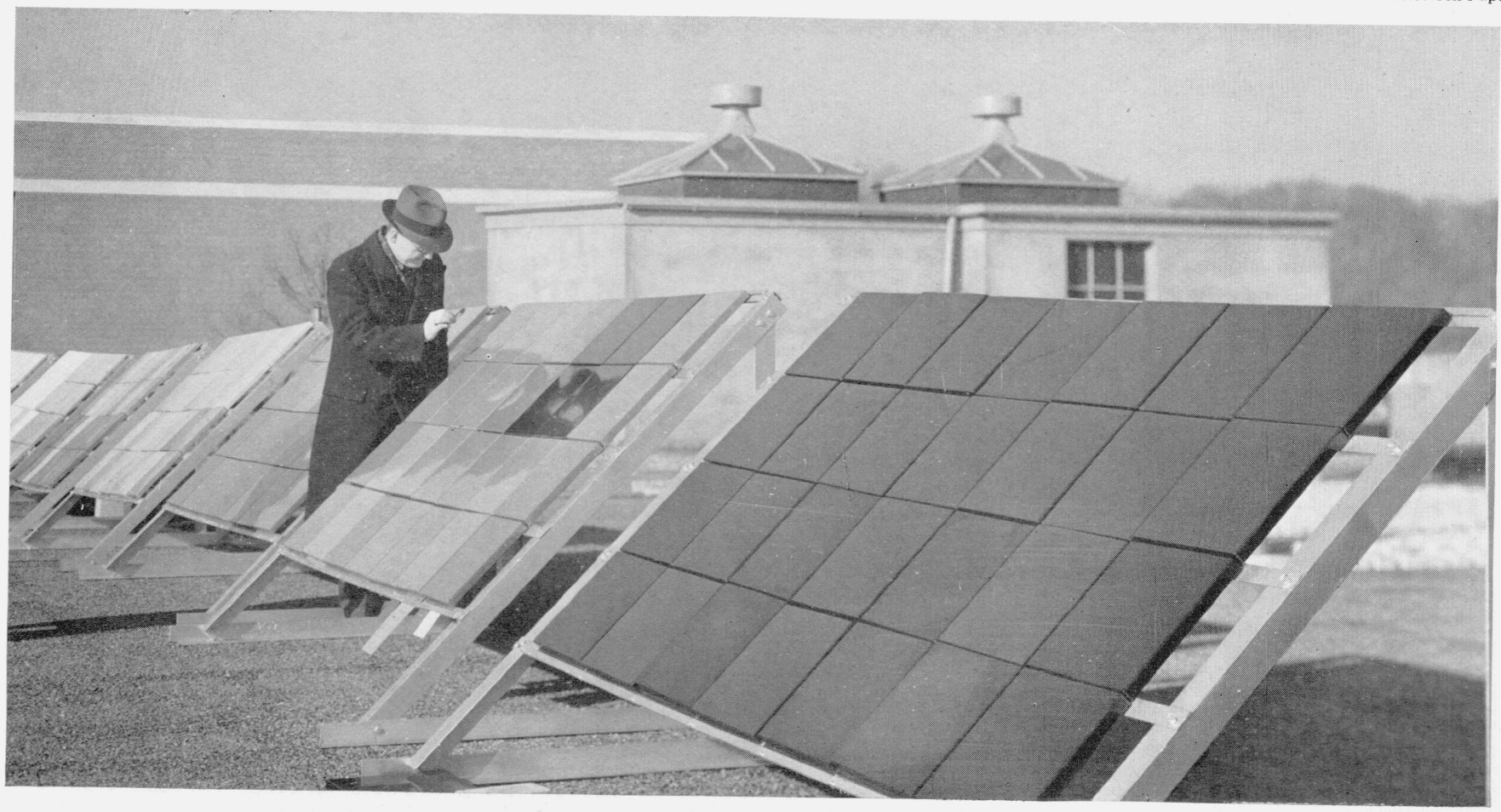

Figure 1.-Specimens in racks as exposed on a roof at the National Bureau of Standards, Washington, D. C. 

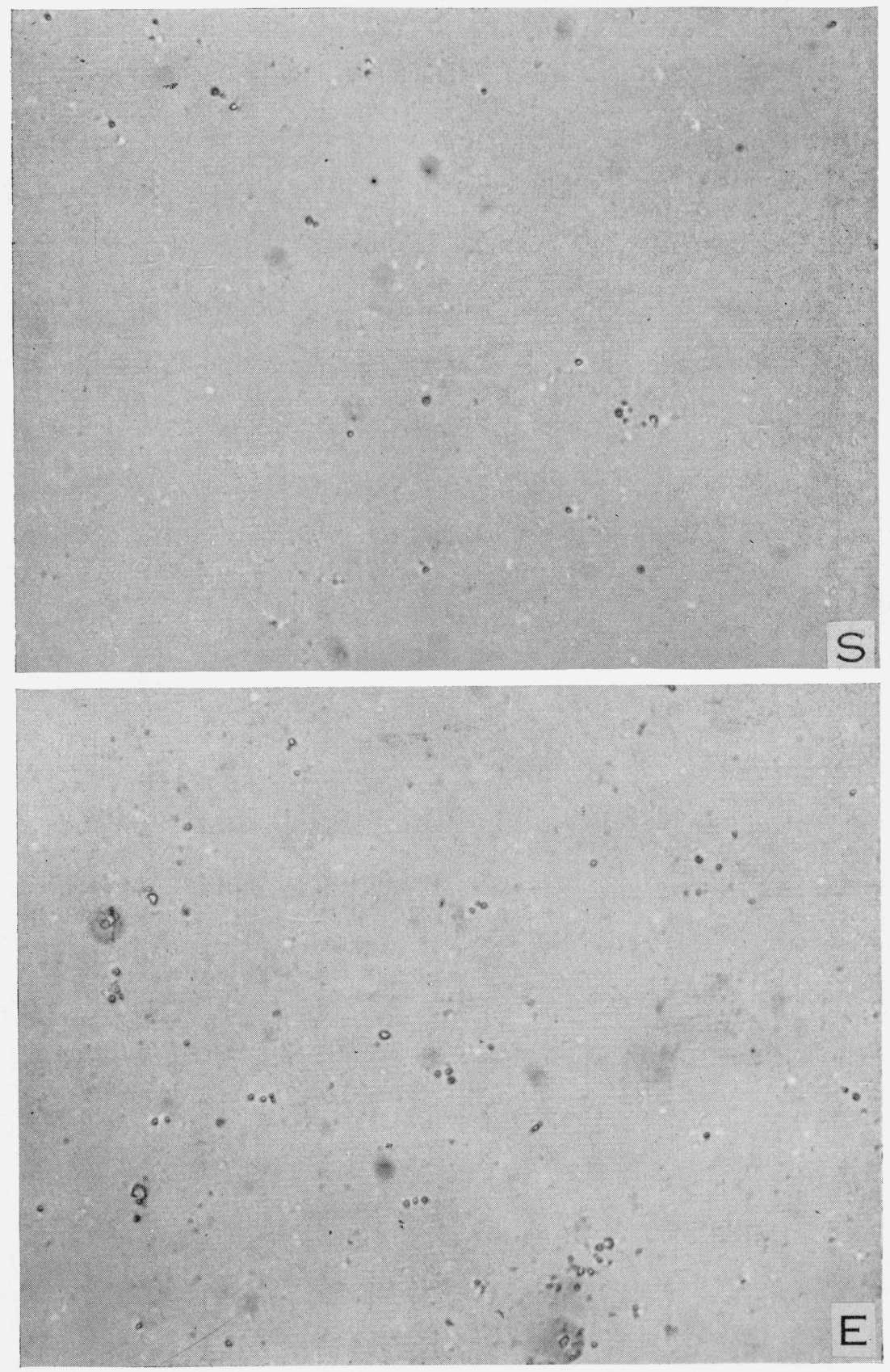

Figure 2.-A typical black, acid-resistant, glossy enamel, showing no change in surface microstructure from weathering.

$\mathrm{S}$ is storage panel $\mathrm{T}-69 . \quad E$ is a duplicate panel $\mathrm{T}-61$ after 1 year of exposure in Washington, D. C., showing no noticeable change in appearance. Specks are probably mill additions. $\times 600$. 

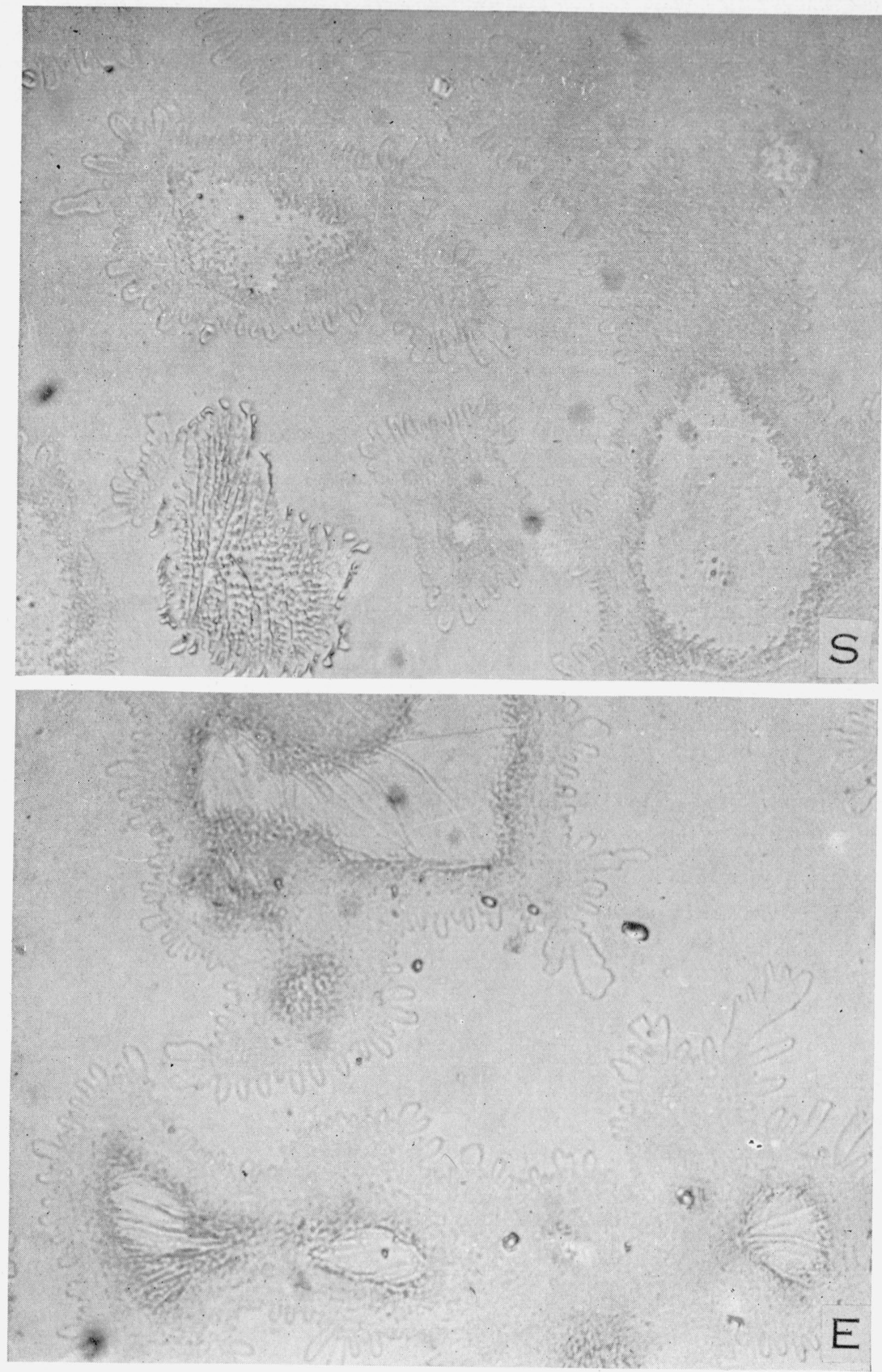

Figure 3.-Black, acid-resistant, glossy enamel, showing no change in microstructure from weathering.

$S$ is storage panel T-29. $E$ is duplicate panel T-22 after 1 year of exposure in Washington, D. C. The visible material exposed at surface is partially dissolved mill addition. $\times 600$. 


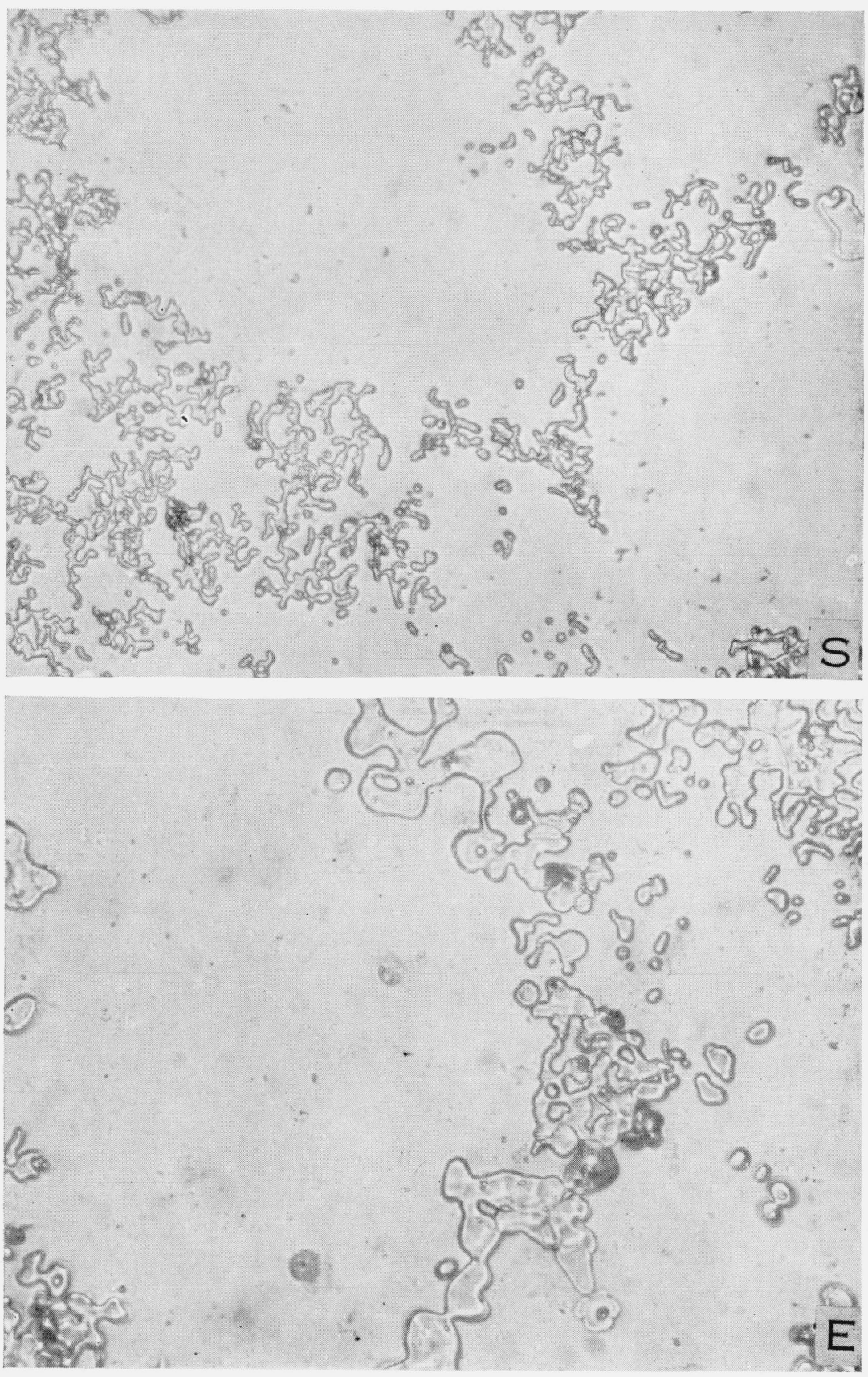

FigURE 4.-Red, semimat enamel of good acid-resistance, showing no change in surface microstructure from weathering.

$S$ is storage panel $\mathrm{P}-49 . \quad E$ is duplicate panel $\mathrm{P}-41$ exposed at Washington, D. C., for 1 year. Particles exposed at the surface are undissolved material added to give a mat finish. The difference in size of the exposed material probably is not significant. $\times 600$. 

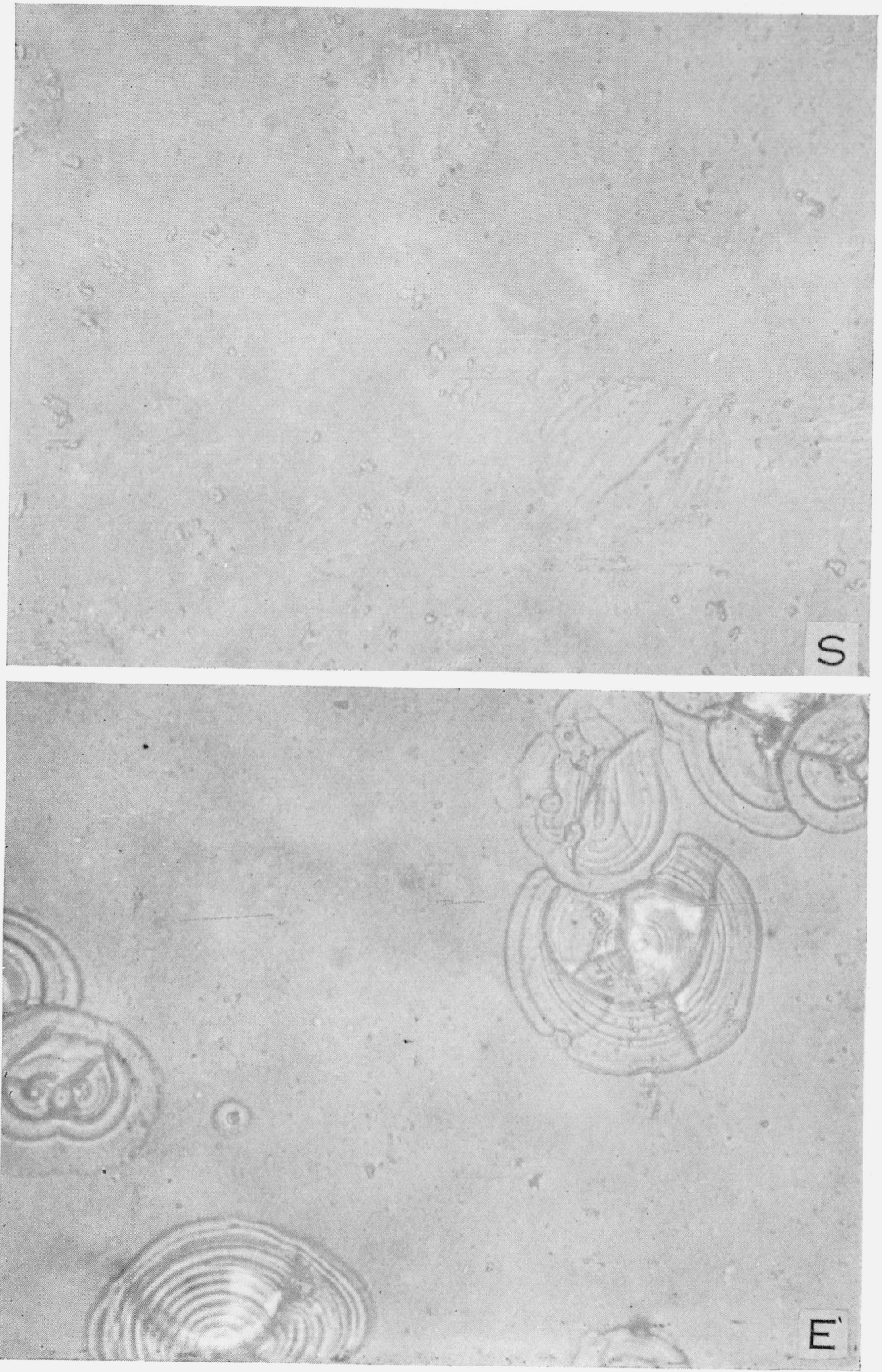

Figure 5.-Red, glossy, non-acid-resistant enamel, showing minute pitting of surface (greatly enlarged) usually associated with enamels of poor weather resistance.

$S$ is storage panel $\mathrm{N}-39$ and $E$ is panel $\mathrm{N}-31$ exposed for 1 year at Washington, D. C. Largest pit in $E$ is 0.002 inch in diameter and of the order of 0.0001 inch in depth. The pits give the general effect of fading or scumming, and appear as tiny white or light-colored specks on close visual examination. $\times 600$. 

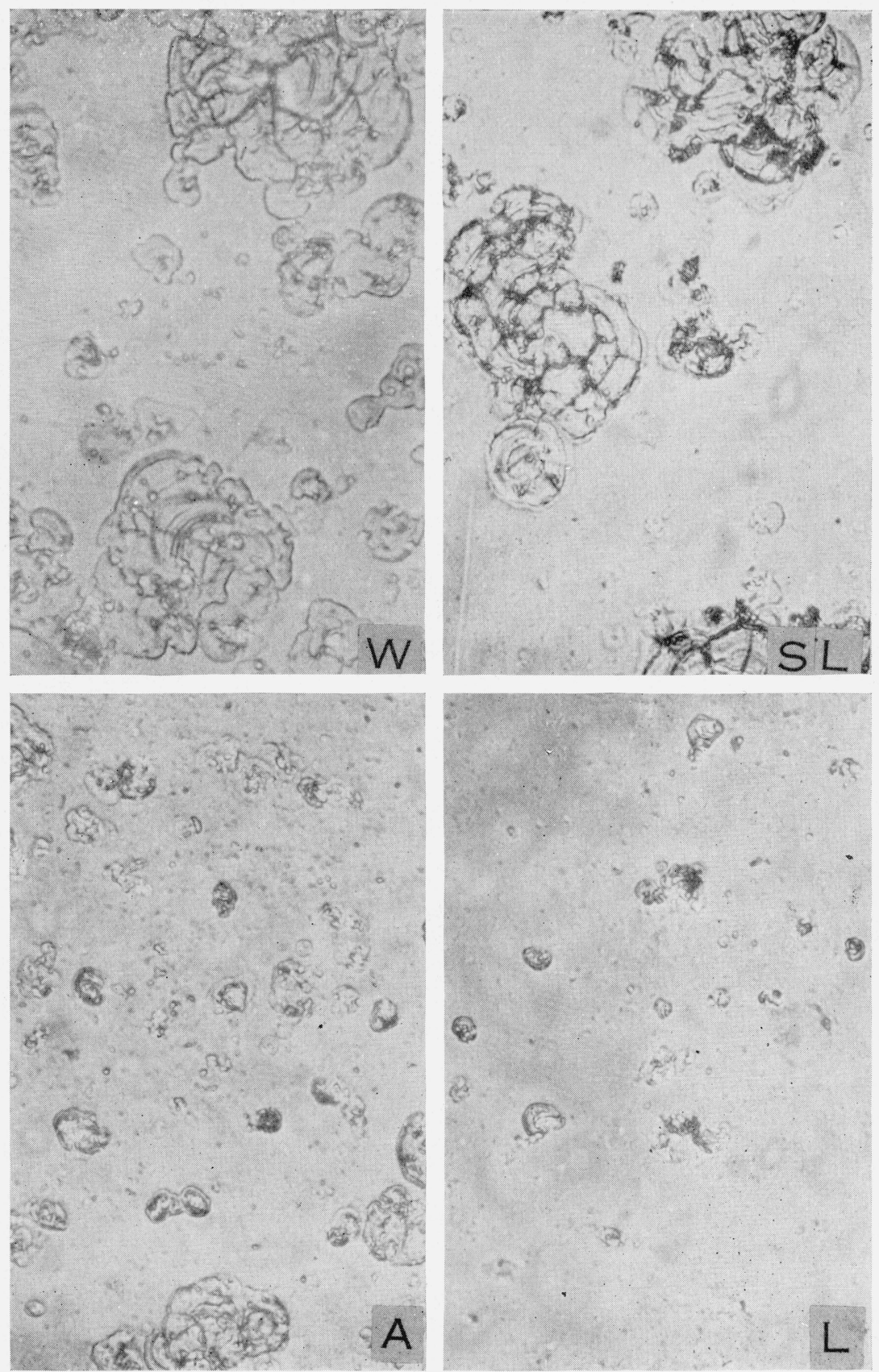

Figure 6.-One of the least resistant enamels studied, illustrating the relative severity of exposure at the four locations.

This enamel was a black, glossy, non-acid-resistant type.

$W$ is panel V-31 exposed at Washington, D. C.; $S L$ is panel V-36 exposed at St. Louis, Mo.; $A$ is panel V-37 exposed at Atlantic City, N. J.; and $L$ is panel V-33 exposed at Lakeland, Fla. The appearance of the stored panel is similar to $S$ in figure 2. Lakeland showed the least pronounced pitting, Atlantic City slightly more, and Washington and St. Louis the most. The darker appearance of the pits in the St. Louis panel is probahly due to a dingy deposit not removed from the pits by scouring. $\times 600$. 

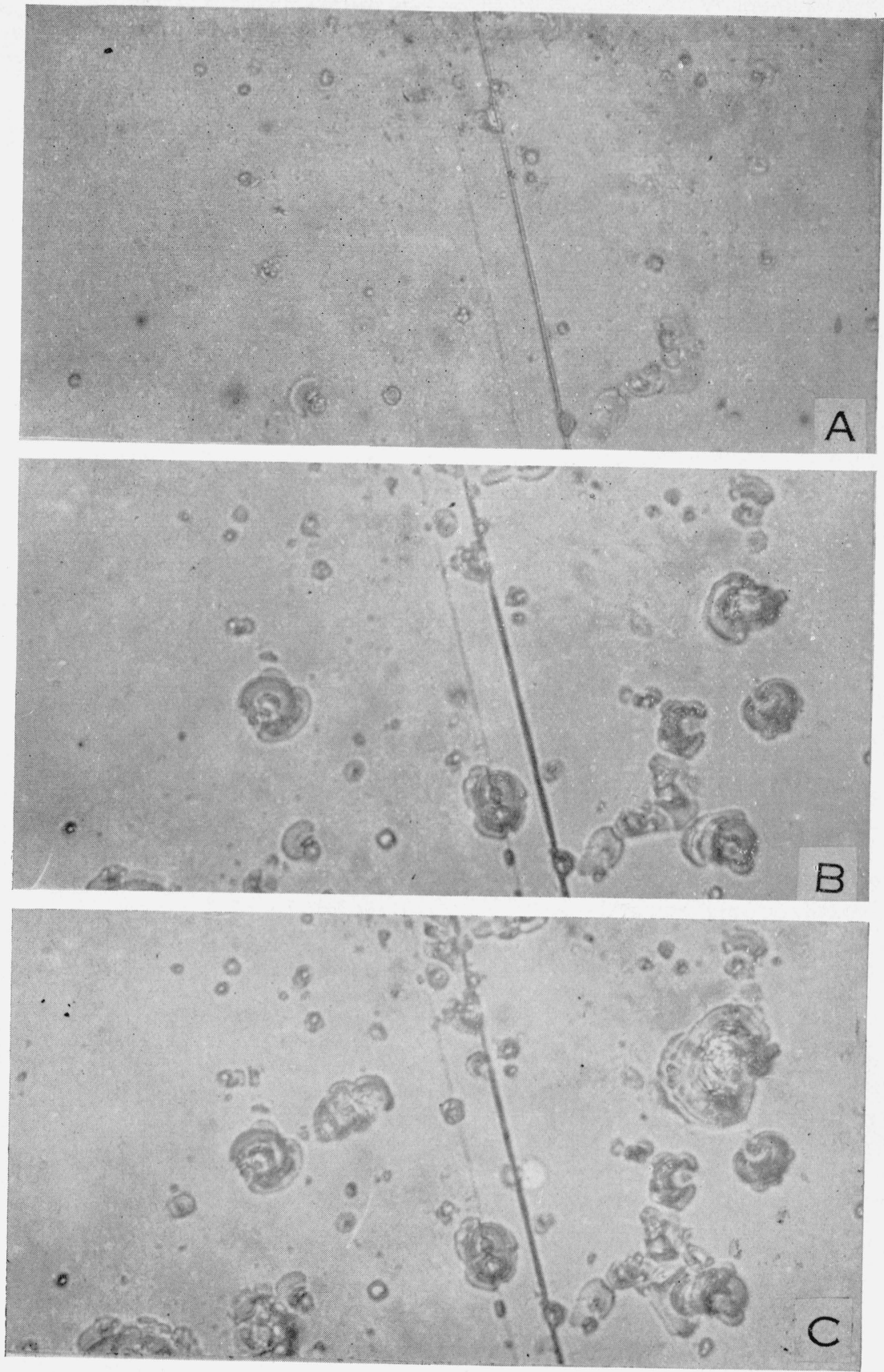

FIGURE 7.-Three views of the same field of a red, glossy, non-acid-resistant enamel of least weather resistance taken progressively during the first year of exposure.

Four- by six-inch specimen N-73, exposed at Washington, D. C. As the duration of exposure increased indicated by the sequence $A, P, C$ ), the pits grew in size and a few new pits developed. Diagonal
lines through center are scratches on surface. $\times 600$. 

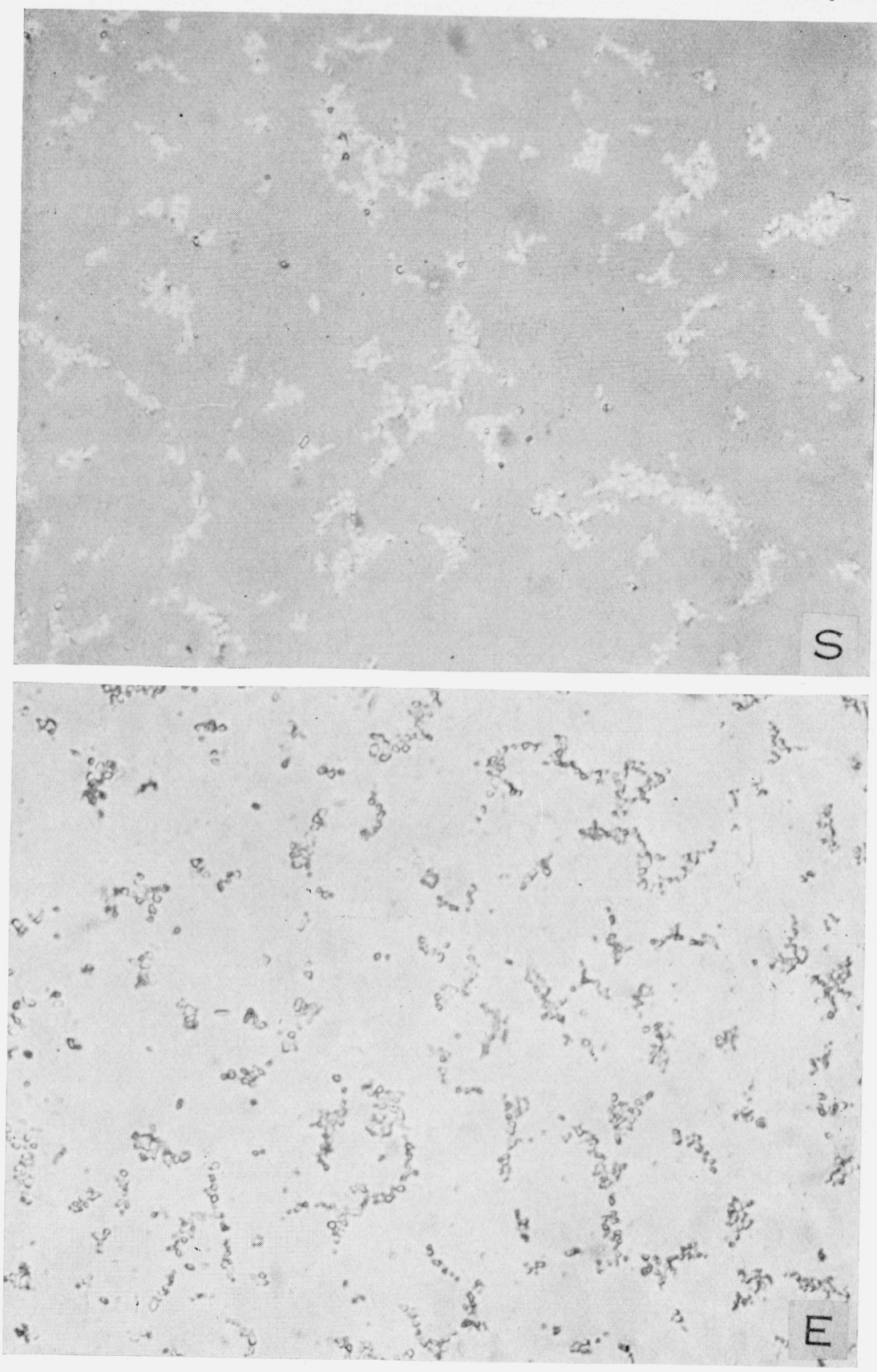

Figure 8.-A black, glossy, acid-resistant enamel, exhibiting a type of weathering of the enamel surface not associated with pitting.

$S$ is storage panel T-1 and $E$ is panel T-7 exposed at Atlantic City for 1 year. Particles in $S$ appearing light in micrograph are mill additions of black oxide which have altered during weathering to give a dark appearance in the exposed panel $E$. The alteration produced a very slight dulling and graying of the
enamel. $\times 600$. 
and only one enamel of class $B$ acid resistance developed any pits. On the other hand, all the enamels of class $C$ or $D$ acid resistance showed pitting to varying degrees. The full-mat enamels are excepted from these statements regarding pitting, since the surface texture was such that pitting would be difficult to detect, and furthermore the full-mat enamels are considered unsuitable for architectural use where appearance is important, for reasons discussed elsewhere in this paper.

The severity of pitting of these non-acid-resistant enamels was found to be considerably influenced by the location of exposure, as indicated in figure 6 . In general, pitting was most severe at Washington and St. Louis, and least severe at Lakeland, with Atlantic City falling between. The dingy film mentioned previously as being present on the St. Louis panels shows up in figure 6 as being firmly imbedded in the pits of the St. Louis panel. This particular panel had been cleaned with a scouring powder before the microscopic examination; a cleaning procedure which was apparently successful in freeing the surface of all the film on those areas where pits were not present.

That the severity of the weathering action is associated with the size of the pits is brought out by figure 7 . This series of photomicrographs was taken on the same field of a red, non-acid-resistant enamel at various intervals during the first year of exposure. It will be noted that some new pits continue to occur, and that the size of the pits existing at any stage increases noticeably, on the average, as weathering progresses.

Those enamels showing least resistance to pitting at Washington also showed least resistance at the other locations. Indications are that, while the severity of pitting varies with the location of exposure, the general set of conditions causing the pitting are the same at the four locations and vary only in intensity.

Besides the pitting, microscopic examination brought out another type of surface change on at least one enamel. This is illustrated in figure 8 by the black, acid-resistant panels $T-7$ and $T-9$. So far as could be determined, the visible conglomerates of material in these photomicrographs consist of black oxide (pigment) which was exposed at the surface. This material apparently weathered during exposure, causing a loss in glossiness and a very slight graying of the enamel, the total visible effect of weathering being small. The same change in surface appearance of this enamel was found at all four locations to about the same degree. Another black, acid-resistant enamel made from the same frit, $\mathrm{T}-11$ to $\mathrm{T}-19$, but prepared by another fabricator, did not show this effect. Special inquiry was made to determine whether the mill additions, though nominally the same, were actually different, but so far as could be determined both fabricators used identical mill batches.

\section{MEASURED COLOR CHANGE}

Complete color measurements were not made on all the enamels at the end of the first year, inasmuch as a large part of the panels showed no visually detectable fading, and for those enamels on which fading was visible the changes were usually slight. Only the few full-mat 
specimens that showed changes which were readily apparent to the eye were measured. The outstanding case of fading was observed in panels S-1 to S-8. At St. Louis, the fading of these panels amounted to as much as 25 NBS units [7]; at Washington, 18; at Atlantic City, 14; and at Lakeland, 10 . Thus, for the avoidance of fading, as well as to retard the accumulation and retention of surface grime, it may be concluded that full-mat surfaces should be avoided.

\section{SPECULAR-GLOSS IMEASUREMENTS}

The initial gloss measurements were standardized against a liquid film [8] to ensure that no change in the standard would occur by aging and were all made in Washington. The first-year measurements were made at the exposure sites with the same multipurpose reflectometer, and with the same liquid-film standard. The exposed panels were prepared for measurement by the same treatment as that used for obtaining the initial values. The film previously mentioned as being present on the St. Louis panels was not completely removed by scouring, inasmuch as such treatment would tend to give values not strictly comparable with the initial measurements made on the panel surfaces washed with a solution of trisodium phosphate. However, because the St. Louis measurements of the percentage gloss retained were in agreement with visual estimates, and also because they follow the same general trends found at the other locations, it is believed that the film did not seriously affect the value of the specular-gloss measurement.

The changes in specular gloss at the end of the first year of weathering are summarized in table 3 and further condensed in table 4. The over-all averages for percentage gloss retained, which are listed in table 4, show the average loss of specular gloss to be greatest at Washington, D. C., with St. Louis, Atlantic City, and Lakeland following in that order. That the glossy and semimat enamels, on the average, are not appreciably different in weathering resistance is indicated by the same table. The full-mat enamels, which showed considerable fading, could not be measured for loss of gloss.

TABLE 4.-Percentages of initial specular gloss retained by different classes of enamels at the several locations and in the carbon dioxide test

\begin{tabular}{|c|c|c|c|c|c|c|}
\hline \multirow{3}{*}{ Types of enamel } & \multicolumn{6}{|c|}{ A verage percentage of initial specular gloss retained } \\
\hline & \multicolumn{4}{|c|}{ City } & \multirow{2}{*}{$\begin{array}{l}\text { Average } \\
\text { of the } \\
\text { four } \\
\text { locations }\end{array}$} & \multirow{2}{*}{$\begin{array}{c}\text { Carbon } \\
\text { dioxide } \\
\text { test }^{1}\end{array}$} \\
\hline & $\begin{array}{l}\text { Washing- } \\
\text { ton }\end{array}$ & St. Louis & $\begin{array}{l}\text { Atlantic } \\
\text { City }\end{array}$ & Lakeland & & \\
\hline $\begin{array}{l}\text { Acid resistant, glossy }{ }^{2} \\
\text { Acid resistant, semimat }{ }^{2}\end{array}$ & $\begin{array}{l}89.6 \\
89.6\end{array}$ & $\begin{array}{l}90.3 \\
89.6\end{array}$ & $\begin{array}{l}89.2 \\
93.4\end{array}$ & $\begin{array}{l}92.2 \\
90.7\end{array}$ & $\begin{array}{l}90.4 \\
90.8\end{array}$ & $\begin{array}{l}94.7 \\
96.6\end{array}$ \\
\hline A verage, acid resistant ${ }^{2}$ & 89.6 & 89.9 & 91.3 & 91.4 & 90.6 & 95.6 \\
\hline $\begin{array}{l}\text { Nonacid resistant, glossy } \\
\text { Nonacid resistant, semimat....... }\end{array}$ & $\begin{array}{l}73.2 \\
74.6\end{array}$ & $\begin{array}{l}78.9 \\
80.9\end{array}$ & $\begin{array}{l}82.4 \\
83.2\end{array}$ & $\begin{array}{l}85.1 \\
85.7\end{array}$ & $\begin{array}{l}79.9 \\
81.0\end{array}$ & $\begin{array}{l}77.4 \\
74.9\end{array}$ \\
\hline A verage, nonacid resistant....- & 73.9 & 79.9 & 82.8 & 85.4 & 80.5 & 76.2 \\
\hline
\end{tabular}

1 See page 748 for description of carbon dioxide test.

2 A few of the nominally acid-resistant specimens were class $B$ or lower in the Porcelain Enamel Institute standard test for acid resistance, but these specimens were not included in the averages for acid-resistant enamels. 
The average values of initial specular gloss retained for all acidresisting enamels, when compared to those of the non-acid-resisting enamels, show that at each location the non-acid-resisting enamels have significantly lower values. This same relation exists throughout all of the enamel types.

With regard to extremes, table 3 shows that, at the end of the first year, the buff, glossy, acid-resistant enamels, as a group, had retained the highest percentage of their specular gloss, whereas the black, glossy, non-acid-resisting panels retained the least.

\section{ACCELERATED WEATHERING TESTS}

The need for an accelerated weathering test for vitreous enamels is obvious. The ideal test, of course, would be one which would correlate so well with actual weathering that predictions could be made on any given enamel as to its probable useful service life at any normal location. One of the objectives of this investigation was to develop an adequate accelerated test. There follows a description of several accelerated tests which were investigated.

\section{RADIATION TESTS}

Several radiation tests were made, using the 4 - by 6 -in. laboratory specimens with enamels of the same compositions as those of the panels exposed outdoors. An exposure time of 500 hours was used and four distinct tests were included. These were:

1. Unfiltered carbon-arc radiation, using "sunshine" carbons which give radiation roughly simulating the shorter wavelengths of sunlight.

2 . The same radiation as above, except that the radiation was alternated with a water spray. [9]

3. Carbon-arc radiation, using special carbons giving higher concentrations of the shorter ultraviolet radiation.

4. Mercury-arc radiation.

None of these tests was effective in producing any noticeable breakdown of the enamel, a result which is in agreement with previous work reported by Ammon [1]. The only change noted was a slight loss of specular gloss, which was found to be greater for the acidresistant enamels than for the non-acid-resistant. In only two enamels, $\mathrm{T}-1$ and $\mathrm{T}-21$, was there any line of demarcation, visible to the naked eye, between the exposed and unexposed areas. From the results of these tests, it seems probable that sun radiation plays only a very minor part in the weathering of vitreous enamels.

\section{AUTOCLAVE TESTS}

Autoclave tests were made on all enamels included in the investigation. The 4 - by 6 -inch laboratory specimens were used for this purpose, and these were immersed to a depth of 3 inches in distilled water in a Pyrex beaker. The autoclave was electrically heated, and the power input was so regulated that the temperature was raised to $150^{\circ}$ $\mathrm{C}$ in 90 minutes, held at $150^{\circ} \mathrm{C}$ for 5 minutes, and cooled from $150^{\circ}$ to $80^{\circ} \mathrm{C}$ in 150 minutes. The total time above $100^{\circ} \mathrm{C}$ was 185 minutes.

Surface attack was evaluated both by visual examination and by gloss measurements. Although the results showed appreciable differ- 
ences in the various enamels, no correlation was observed between these results and those obtained from actual weathering.

\section{MisCELLANEOUS TESTS With WATER}

During the early stages of the investigation, it was considered possible that the pitting of the non-acid-resistant enamels might be caused by the action of moisture together with either subsequent freezing and thawing or the heating of the surface by sun radiation. To test this hypothesis, several enamels of low pitting resistance were exposed to the following conditions:

1. Continuous water spray for 72 hours, followed immediately by freezing.

2. Boiling for 2 hours, followed by freezing.

3. Boiling for 2 hours, followed by heating the specimens over a gas flame.

None of these tests produced any noticeable breakdown of the enamel nor did the results correlate in any way with the results obtained on the exposed specimens.

\section{ACID-RESISTANCE TEST}

The standard test of the Porcelain Enamel Institute for the acid resistance of flatware [6] was made on the 4 - by 6 -in. specimens of all enamels included in the study. These results are reported in table 3. It will be noted that there is a definite correlation between acid resistance and durability, the enamels of high acid resistance weathering less, on an average, than those of poor acid resistance. This same correlation has been noted previously by both Ammon [1] and Sweo [2].

\section{CARBON DIOXIDE TEST}

Carbon dioxide is the ouly acidic gas present in an appreciable quantity in uncontaminated air. For example, the carbon dioxide content of the air in busy thoroughfares will average 0.05 to 0.09 percent, by volume, whereas clean air will give an average analysis of 0.03 percent of carbon dioxide. It was believed possible that this gas might be a factor in enamel weathering and, hence, one of the first attempts to devise an accelerated test by means of weak acids was made using this gas.

The carbon dioxide test which was developed consists in exposing the specimens, while partially immersed in distilled water, to carbon dioxide under a pressure slightly above atmospheric, resulting, of course, in the formation of carbonic acid. In making a test, the pressure chamber was first flushed with carbon dioxide, and the needle valve on the carbon dioxide supply tank then adjusted to give a flow of 1 or 2 milliliters per minute through the pressure regulator, which was set to give a pressure equivalent to 4 inches of mercury. This pressure was held for 17 hours, after which the specimens were removed and dried in an oven at $110^{\circ} \mathrm{C}$.

Figure 9 is red, acid-resistant enamel $\mathrm{N}-31$, after actual weathering, as compared with a duplicate specimen which had undergone the carbon dioxide test. The pits resulting from the carbon dioxide test, although not identical in size and shape with those on the panel which had undergone actual weathering, were nevertheless of the same 

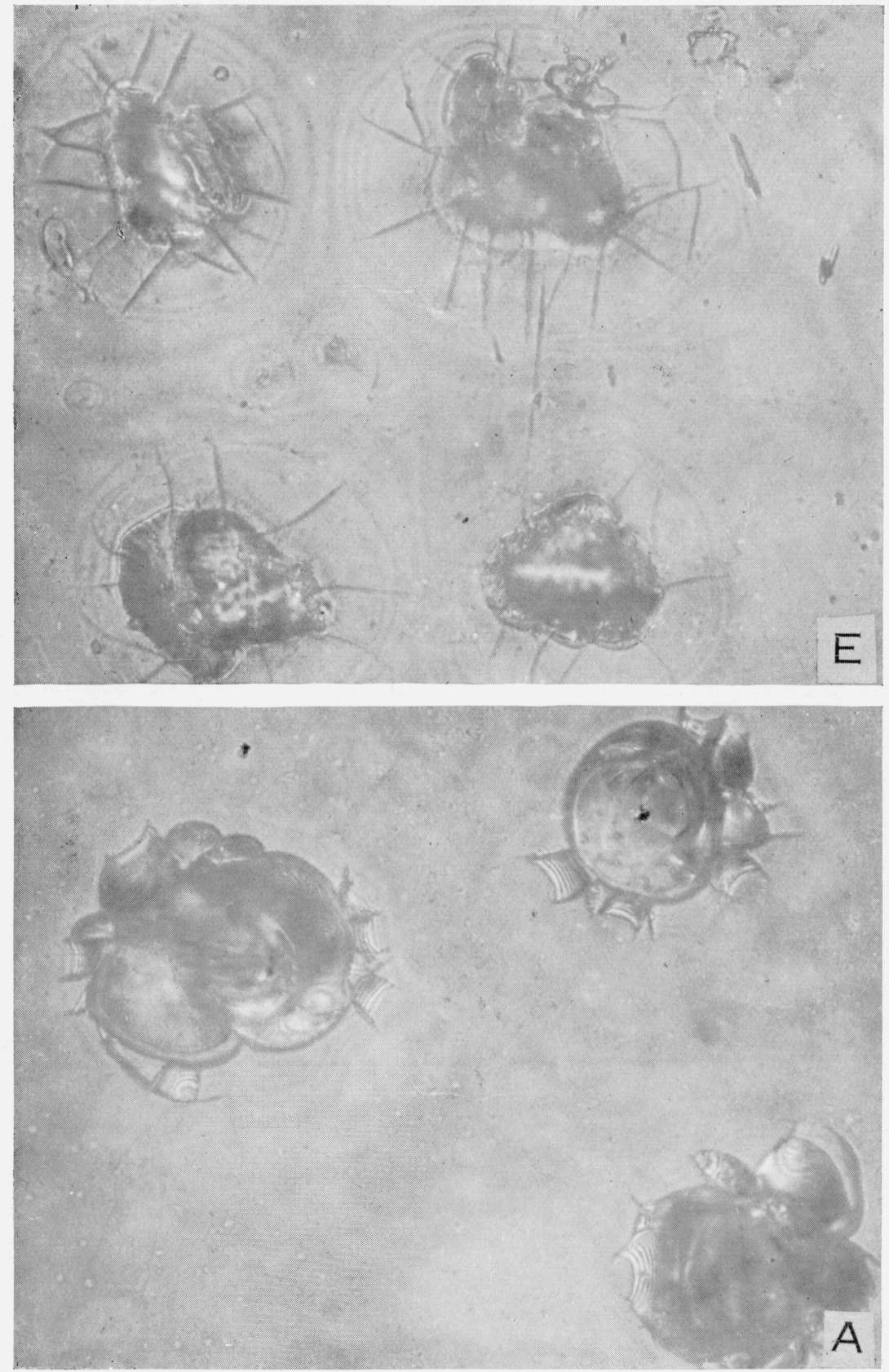

FIGURE 9.-Comparison of pitting of a red, glossy, non-acid-resistant enamel after exposure to weathering $(E)$ and after exposure to the carbon dioxide (accelerated weathering) test $(A)$.

$E$ is panel N-52 after exposure in Washington, D. C., for 1 year. $A$ is 4- by 6 -inch laboratory specimen $\mathrm{N}-56$ after exposure to the carbon dioxide test described in the text. $\times 600$. 


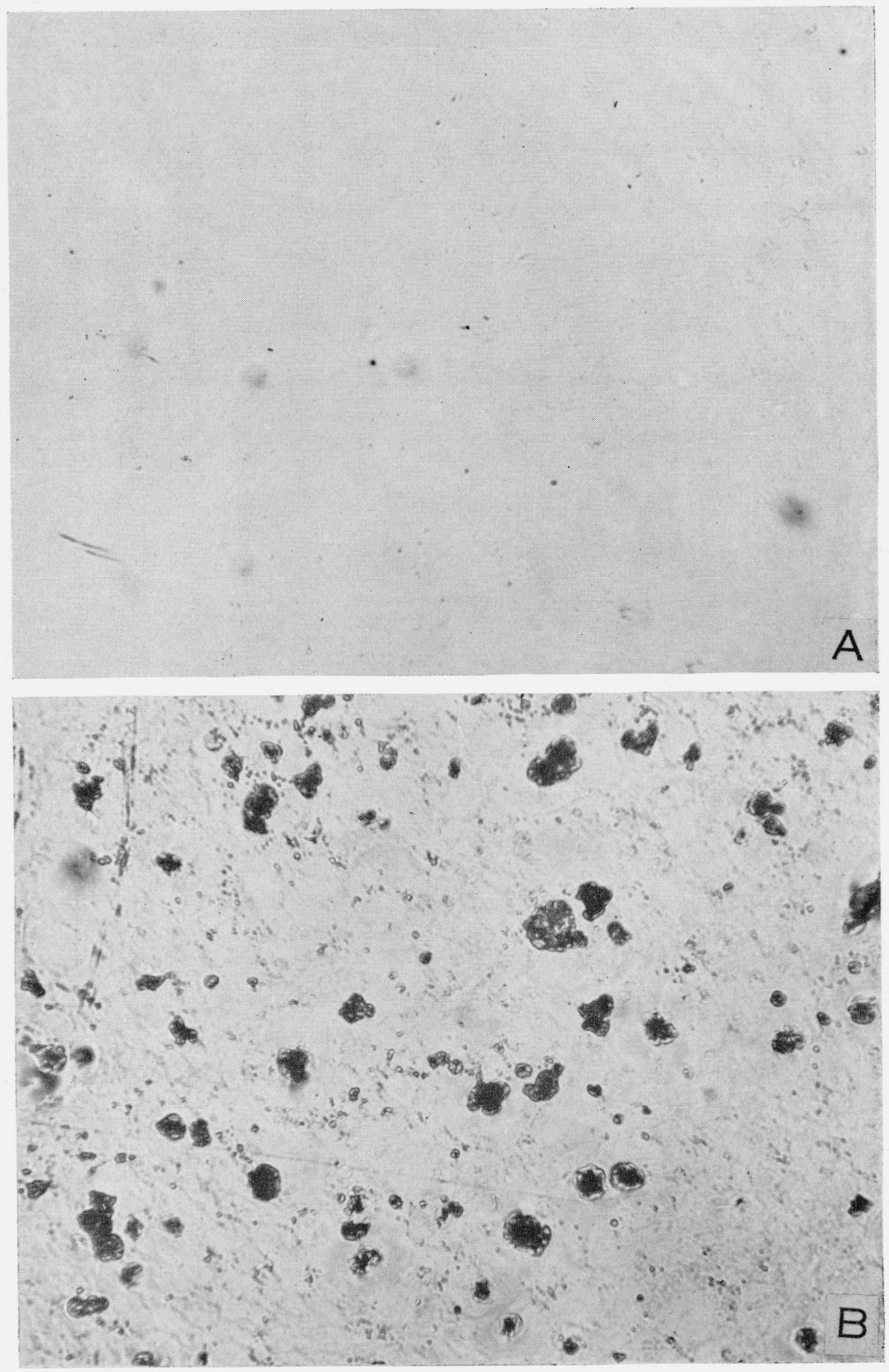

FIGURE 10.-Protection from pitting obtained by applying a clear, acid-resisting overglaze to a red, glossy, non-acid-resistant enamel.

$A$ is area on 4 - by 6 -inch specimen N-47 protected by a thin coating of clear, acid-resistant overglaze. $B$ is unprotected area on the same specimen. The specimen was exposed for 6 months at Washington, D. C. $\times 85$. 
general type and appeared to be formed from the same mechanism. None of the other accelerated tests gave effects similar in appearance to those of actual weathering.

The average percentages of initial specular gloss retained on the immersed part of the specimens subjected to this test are given in table 3. It will be noted that, in most cases, there is a good correlation between these data and the gloss data on specimens subjected to actual weathering, but there are exceptions to this agreement. These may be explained in part by the possibility that (1) the 4- by 6 -in. specimens are not identical with the larger panels used for the actual exposure, or (2) other factors beside weak acid attack may be responsible for some of the effects noted in the weathered panels.

Microscopic examinations of the specimens after the carbon dioxide test showed that pitting had occurred on the same enamels which pitted in actual exposure. However, it was found that in only rare exceptions did this pitting show up when the specimens were first removed from the pressure chamber. For the pits to appear, it was first necessary to dry the surface thoroughly. Drying at room temperature and room humidity for prolonged periods caused practically no pitting. However, when these air-dried specimens were heated slightly, the flaking immediately appeared on the enamel surface. Likewise, when the specimen was placed in a desiccator over lump calcium chloride, the pits began to appear within a few seconds.

Plunging the specimen in boiling water caused the pits to appear only if it was removed from the hot water and allowed to dry in air. If the specimen was allowed to cool in the water, the surface was unchanged and no pitting was present.

One explanation of the behavior described above is the possible development of a gelatinous film on the enamel surface as a result of weathering. This film could be formed during the carbonic acid treatment by a leaching of alkali from the enamel, leaving a thin surface layer of gel high in silica. This gel, adhering tenaciously to the underlying enamel, would contract on drying and in so doing cause large forces to be set up in the enamel surface. Some idea of the magnitude of the force exerted by a drying gel may be obtained by coating a glass plate with gelatin which has absorbed a maximum amount of water and observing the degree to which the glass plate is bent by the drying film. The strain is frequently sufficient to break the plate or to pull pieces of glass from the surface [10]. It is thought that the pitting in the surface of the non-acid-resistant enamel might conceivably occur from a similar mechanism. The strain introduced by shrinking of the gel would be released by fracture of the enamel surface. The selective nature of the pitting may possibly be caused by small local differences in acid resistance over the enamel surface, or to failure starting at points of weakness, such as surface flaws or discontinuities caused by the presence of particles of mill addition at or near the enamel surface. It is also possible that the pits are entirely confined to the gel-like layer of the surface and do not penetrate into the underlying enamel.

For the gel theory to be valid, other weak acids besides carbonic (or weak solutions of strong acids) should also be effective in causing pitting, inasmuch as they would also be expected to produce gelatinous films. That such is the case was demonstrated by immersing speci- 
mens for 17 hours in weak concentrations of various organic and inorganic acids. A type of pitting which closely resembled the pits from the carbon dioxide treatment was produced in most of these tests. However, owing to the leaching of alkali from the enamel surface, the $\mathrm{pH}$ of these weak solutions changed greatly during test, thus making them unsuitable for an accelerated test without either continuous replacement of solution, or the addition of a buffer. When acid solutions buffered at $\mathrm{pH}$ from 4 to 5 were used, however, the attack no longer resembled that found on weathered enamels. The outstanding advantage of the carbon dioxide test as compared with the use of other weak acid solutions is, that the desired steady condition can be maintained by a slight flow of carbon dioxide.

\section{SURFACE COATING TO INHIBIT WEATHERING}

From the foregoing data, it is apparent that acid-resistant enamels in this study have proved far more resistant to weathering, on the whole, than non-acid-resistant ones. The obvious indication is that, in order to prevent or at least minimize pitting, a thin coating of a clear acidresistant overglaze, preferably class $A$ or $A A$ in the standard test of the Porcelain Enamel Institute, might be applied over the non-acidresistant surface. This type of coating is not new in the enamel industry, since it has been used in particular as a final protective coating in the manufacture of porcelain-enameled tabletops. In this study, it was found possible, by proper selection of the overglaze frit and the mill additions, to apply the coating without appreciably changing the color of the underlying enamel.

Figure 10 shows 4 - by 6 -in. laboratory specimen $\mathrm{N}-47$ after 6 months' weathering at Washington, D. C. Half of this specimen $(A)$ was coated in the Bureau laboratory with a thin layer of a clear, acidresistant enamel, and the other half $(B)$ was left uncoated. The area of the specimen which was uncoated showed pronounced pitting, whereas the coated half showed no detectable change.

\section{DISCUSSION}

From the standpoint of protection of the metal against corrosion, all of the enamels were satisfactory throughout the period covered by this report. Practically all the panels showed some measurable change in surface properties, but in most cases these changes were not noticeable unless comparisons were made with the test specimen in juxtaposition to the storage specimen of like composition. Even the colored, full-mat enamels, in which the fading was pronounced, were uniform in color over the entire surface, so that the extent of the fading was not apparent without a comparison surface. With the exception of these full-mat, and a few of the black, non-acid-resistant enamels, the changes in appearance taking place over the first year of exposure could hardly be considered objectionable.

The fact that the enamels showed their best resistance in those climates which are most severe on paint and on metals (North Atlantic seacoast and Florida) indicates that the mechanism of weathering is entirely different.

The results of the first-year inspection indicate that general climatic conditions at any particular location of exposure are of only minor 
importance as compared to atmospheric contamination by acidic gases. For example, table 2 shows the total rainfall at Lakeland to be twice that at St. Louis and the average temperature $14^{\circ} \mathrm{F}$ higher. Both of these conditions are factors which might be expected to accelerate weathering, yet the St. Louis exposure was by every criterion the more severe. The answer would seem to lie in the relatively high concentration of combustion products in the St. Louis atmosphere and their practical absence at the Lakeland exposure.

The fact that the Washington panels, on the average, showed the greatest loss of specular gloss requires explanation, if weathering is ascribed to the action of acidic gases. Table 2 shows the sulfur dioxide content of the air to be many times greater in St. Louis than in Washington, but the Washington gas analysis was made on a street about 200 yards from a heating-plant stack, whereas the exposure location is on a roof only 50 yards distant, where concentrations would be much higher. Also, it is thought that the accumulated surface coating which gave a dingy appearance to the St. Louis panels may possibly have acted as a protective film over the panel face and thus retarded weathering action. In addition, the discharge of gases from chemical hoods at the Washington site should not be discounted entirely as a possible explanation for the greater attack.

The weathering of the Atlantic City panels also may be due in large part to the products of fuel combustion. The gases originate in the city, and smoke movement toward the location of exposure was noted on several occasions during the inspection. Owing to the nearness of these panels to the water, there is considerable dampness, and the panels undoubtedly become wetted at night during the summer, even in dry weather. The action of "salt" air, so far as can be determined from the first-year inspection, is of little importance in affecting the resistance of the enamel to weathering.

The minute pitting of the non-acid-resistant enamel surfaces, as illustrated in many of the photomicrographs, is believed to be the most serious effect so far observed in the weathering of porcelain enamels. It should be emphasized, however, that this pitting was observed only on the enamels of poor acid resistance, and was not apparent by visual examination except on the colored panels. the same type of pitting was observed by microscopic examination on the white, non-acid-resistant enamels, but there was no accompanying change in the appearance of the white surfaces.

It should also be pointed out that this pitting, in any stage so far observed, is objectionable only insofar as the appearance of the panel is concerned. The pits which appear as white specks on the surface of the colored enamels make the panels appear lighter and weaker in color. The darker colors, as might be expected, exhibit the greatest change in appearance from this phenomenon, the blacks showing the greatest change.

On the basis of the first-year inspection, it appears likely that many years would be required before the pitting could progress to the point at which the underlying metal would be exposed.

The gloss data were found to correlate well, for the most part, with the visual estimates of attack and also with the microscopic examinations. The decrease in the glossiness of the enamel surface during weathering may be influenced by the following factors: 
1. A general filming of the surface, due possibly to hydration and change in the chemical structure of the surface, may be active to some extent on all the compositions and may account for the slight loss in gloss evidenced by many of the panels of high acid resistance.

2. Pitting of the surface probably contributes in an important way to the loss of gloss on the non-acid-resistant enamels.

3. Alteration of exposed particles of mill additions was observed on only one enamel (specimens $\mathrm{T}-1$ to $\mathrm{T}-9$; see fig. 8), in which the black oxide exposed on the surface had weathered, and thus decreased the glossiness of the panel.

4. Photochemical action is brought about by sunlight and may be a minor factor in the reduction in gloss of some of the red, and black, acid-resistant panels. Slight losses in gloss were noted after the laboratory ultraviolet radiation tests ${ }^{5}$ on these same red and black compositions and, hence, it is to be expected that similar losses occur in field exposure.

The work on the accelerated tests confirms the conclusion, from the results of outdoor exposure, that acid attack is important in the weather resistance of porcelain enamels. Both the standard citric acid test [6] and the carbon dioxide test, as described in section VII-5, page 748 , correlate fairly well with actual weather resistance, but no correlation was found in any of the other tests attempted. From these results, it is believed to be a logical hypothesis that the weathering of porcelain enamels is largely due to the action of weak acids over long periods of time.

The principal objections to the use of the conventional acid tests as an indication of weather resistance are as follows:

1. There are individual exceptions in which class $A A$ enamels are not as resistant as class $C$, as for example, T-1 and V-1 in table 3 .

2. The type of surface failure obtained, using the conventional type of acid-resistance test, in no way resembles the breakdown obtained in actual weathering.

3. The acid-resistance test is too severe on non-acid-resistant enamels and too mild on the acid-resistant enamels to give the best correlation (see table 3 ).

These objections are largely overcome by using the carbon dioxide test, but it is recognized that all work thus far accomplished on an accelerated test has been done with only the results of the first year of exposure as a guide as to what kind of surface failure is most typical. Longer exposure times may alter the present conception of the best type of test.

As an accelerated weather-resistance test for comparing all types of enamels, the carbon dioxide testis recommended. However, since with few exceptions the glossy and semimat enamels having an acid resistance of class $A$ or class $A A$, according to the standard test of the Porcelain Enamel Institute [6], had good resistance to weathering, it may be assumed, on the basis of the data so far obtained, that this latter test, which is more rapid and easier to perform, is also a valuable guide to weather resistance.

On the basis of results so far obtained, the authors feel justified in making the following recommendations:

\footnotetext{
5 See section VII of this paper, page 747.
} 
1. Where appearance is an important factor, full-mat enamels should not be used for outside installations, since they tend to accumulate and retain a dingy film and to fade.

2. Enamels of acid resistance less than class $B$ (PEI test) should not be used in any architectural installation, if general appearance and absence of fading are important factors in the installation. An acid resistance of class $A$ or class $A A$ probably is to be preferred.

\section{SUMMARY}

The fact that porcelain enamels can be adapted to a wide variety of specialized uses, by proper adjustments in composition, has as its corollary the fact that careful selection is required to obtain the type of enamel best suited to a given use. That weather-resisting enamels are no exception to this rule is indicated by the following summary of results obtained in a study involving 864 panels, most of which were exposed for a year at one of four locations selected to obtain a variety of climatic and atmospheric conditions.

1. More than half the enamels included in the investigation showed no visible effect after 1 year of exposure.

2. The acid-resisting enamels were, as a whole, distinctly more durable than the nonacid-resisting.

3 . The full-mat enamels appeared to be unsuited for architectural use, where appearance is important, because of fading and difficulty in cleaning.

4. Changes in appearance of the surface of the non-acid-resistant colored enamels were, in some instances, noticeable after the first year of weathering. These changes were, in most cases, associated with a pitting of the surface, probably resulting from the presence of acid-forming gases, such as carbon dioxide and sulfur dioxide, in the atmosphere.

5. The formation of these pits on the non-acid-resistant enamels was prevented or inhibited by the application of a thin overglaze of clear, acid-resistant enamel.

6 . Weathering was more pronounced at those locations where there is a relatively high concentration of combustion gases and least severe where there is a practical absence of these gases in the atmosphere.

7. In all cases where visible effects of weathering occurred, the changes were confined to the enamel surface only. In no case was there any failure of the enamel coating to protect the underlying iron from rusting.

This study was made possible by the cooperation of the following companies in supplying the necessary enamel frits and specimens for the study:

Baltimore Enamel \& Novelty Co.

W. A. Barrows Porcelain Enamel Co.

Chicago Vitreous Enamel Product Co.

Davidson Enamel Products Co.

Erie Enameling Co.

Ferro Enamel Corporation.

General Porcelain Enameling and Mfg. Co.

Ingram-Richardson Mfg. Co.

Porcelain Enamel \& Mfg. Co.

Porcelain Metals, Inc. 


\section{Journal of Research of the National Bureau of Standards}

Porcelain Metals Corp.

Porcelain Products Co.

J. M. Seasholtz \& Sons.

Texlite, Inc.

Toledo Porcelain Enamel Products Co.

Wolverine Porcelain Enameling Co.

Acknowledgment is made also to the Porcelain Enamel Institute, whose financial contribution to the installation and inspection of the specimens has been most helpful in carrying through the work according to schedule.

The advisory committee, which offered much valuable assistance in selecting the types of enamel for study and planning the investigation, consisted of P. H. Bates, E. C. Greenstreet, J. I. Irwin, P. B. McBride, Paul Seasholtz, J. D. Tetrick, and H. G. Wolfram.

\section{REFERENCES}

[1] M. G. Ammon, Enamelist, p. 7 (Dec. 1936).

[2] B. J. Sweo, Enamelist, p. 7 (Dec. 1940).

[3] Percy H. Walker, Importance of position in weather tests. Ind. Eng. Chem. 16, 58 (1924).

[4] Air Hygiene Foundation of America, Special Research Series, Bul. 1, pt. 1 (1937).

[5] Richard S. Hunter, J. Research NBS 25, 581 (1940) RP1345.

[6] Test for Acid Resistance of Porcelain Enamels, pt. 1, Flatware (Porcelain Enamel Institute, 919 New York Ave. NW., Washington, D. C., 1940 edition).

[7] R. S. Hunter, Photoelectric Tristimulus Colorimetry, p. 61, ASTM Symposium on Color, March 5, 1941 (American Society for Testing Materials, Philadelphia, Pa.).

[8] D. G. Moore and R. S. Hunter, J. Am. Ceram. Soc. 24, 167 (1941).

[9] Percy H. Walker and E. F. Hickson, Accelerated tests of organic protective coatings, BS J. Research 1, 1 (1928) RP1.

[10] H. B. Weiser, The Hydrous Oxides, p. 33 (McGraw-Hill Book Co., New York, N. Y., 1926 edition).

Washington, March 27, 1942. 